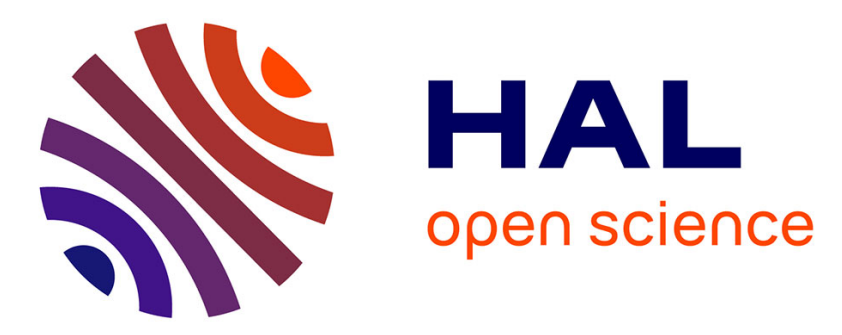

\title{
Adsorption of styrene sulfonate from aqueous solutions onto carbon fibers and mesoporous carbon
}

Véronique Wernert, Renaud Denoyel

\section{To cite this version:}

Véronique Wernert, Renaud Denoyel. Adsorption of styrene sulfonate from aqueous solutions onto carbon fibers and mesoporous carbon. Microporous and Mesoporous Materials, 2016, 222, pp.247255. 10.1016/j.micromeso.2015.10.029 . hal-01476928

\section{HAL Id: hal-01476928 \\ https://hal-amu.archives-ouvertes.fr/hal-01476928}

Submitted on 26 Feb 2017

HAL is a multi-disciplinary open access archive for the deposit and dissemination of scientific research documents, whether they are published or not. The documents may come from teaching and research institutions in France or abroad, or from public or private research centers.
L'archive ouverte pluridisciplinaire HAL, est destinée au dépôt et à la diffusion de documents scientifiques de niveau recherche, publiés ou non, émanant des établissements d'enseignement et de recherche français ou étrangers, des laboratoires publics ou privés. 
Adsorption of styrene sulfonate from aqueous solutions onto carbon fibers and mesoporous carbon

Véronique Wernert, Renaud Denoyel

Aix-Marseille Université, CNRS, MADIREL UMR 7246, 13397 Marseille cedex 20, France

Corresponding author:

Dr. Véronique Wernert

e-mail address: veronique.wernert@ univ-amu.fr

Tel: +33413551840 


\begin{abstract}
The removal of styrene sulfonate from aqueous solution by using different activated carbons, microporous or mesoporous, is studied from kinetics and thermodynamics points of view. The results are interpreted in term of pore size distribution, pore organisation and surface charge. Several classical model are tested both for kinetics and thermodynamics aspects. Very different behaviours are observed between the carbons but for all adsorbents, the kinetics were faster in presence of a saline solution and the amount adsorbed at saturation higher, showing the importance of surface charge that introduces an energy barrier against adsorption when molecules and surface have the same charge. Adsorption isotherms were modelled with Langmuir and double Langmuir equations and the thermodynamic parameters were calculated and correlated with the adsorption behaviours. By using adsorption calorimetry to map the adsorption site distribution, it is possible to validate or not the models.
\end{abstract}

Keywords: styrene sulfonate, kinetics, isotherms, calorimetry, carbon 


\section{Introduction}

As a family of the widespread hydrophobic ionisable organic compounds, aromatic sulfonates are widely used as intermediates for the manufacturing of azo dyestuffs, pharmaceuticals, tanning agents and surfactants. In the past decades water pollution by chemical wastewater has been of increasing concern in many countries. In response to such problems, many practical techniques such as advanced oxidation, membrane filtration, biological degradation, electrochemical oxidation, photocatalytic degradation and adsorption are proposed. Among these methods, adsorption is still the most versatile and widely used, since it can effectively remove many types of pollutants and the design and operation of processes are convenient. To date, activated carbon has been known as the most popularly used adsorbent for pollutants removal. However, a number of problems associated with activated carbon such as pore blocking and slow adsorption rate inhibit its wide application. In recent years, new forms of carbon adsorbent such as activated carbon fibers (ACFs) [1, 2, 3, 4, 5, 6, 7] have been intensively developed and applied. The porous structure of ACF is mainly composed of micropores while the particulate activated carbon have often very complex structure formed by micropores, mesopores and macropores. ACFs have large external surfaces and their micropores are directly exposed on the surface, giving rise to a fast adsorption rate. These nanomaterials have been proven to possess good potential as environmental sensors or superior adsorbents for removing many kinds of organic pollutants such as volatile organic compounds [8,9], natural organic matter [10], dyes [11, 12], polyaromatics hydrocarbons [13], atrazine [14], heavy metals $[15,16]$ from an aqueous solution. In this study we use styrene sulfonate as a model substance having an aromatic structure. Styrene sulfonate and polystyrene sulfonate are also often used as natural organic matter surrogates $[17,18,19,20$, 
21]. The aim of this work is to study the kinetics and isotherm of adsorption of styrene sulfonate onto carbon fibers having different pore sizes and to compare the results with granular mesoporous carbon. In order to understand the adsorption processes and check the validity of classical models, the determination of the adsorption isotherms was combined to the measure of the adsorption enthalpy by microcalorimetry. 


\subsection{Materials}

Styrene sulfonate used as adsorbate in this study is analytical grade (Aldrich) and his main properties are given in table 1 . The size of the molecule was determined with the software Cerius2. Three types of carbons were used: granular mesoporous carbon (Spheron 6) and two kinds of pitch-based ACFs (A5 and A20, Ad'all Co., Japan).

\subsection{Characterization of the carbons}

Carbons were characterized by gas adsorption. Nitrogen sorption isotherms at $77 \mathrm{~K}$ where determined with an ASAP 2010 apparatus from Micromeritics for mesoporous carbon and a Quantachrome Autosorb apparatus for the fibers. The carbons were outgassed at $120^{\circ} \mathrm{C}$ overnight before analysis. The BET equation was applied to determine the surface area of the mesoporous carbon. Average pore diameter and pore volume were evaluated from the nitrogen adsorption-desorption isotherms by applying the Barrett-Joyner-Halenda (BJH) model [22] for the mesoporous carbon. The BJH method is based on the Kelvin equation which defines the equilibrium pressure for capillary condensation and was applied to the desorption branch. The pore size distribution calculations for the fibers are obtained from nitrogen adsorption isotherms by applying the Quenched Solid Density Functional Theory (QSDFT) model assuming slit-shaped pores, which are typical model pores in activated microporous carbon [23]. Raman spectra were obtained using a Horiba-Jobin-Yvon HR LabRAM HR apparatus (laser wavelength: $\lambda_{\mathrm{L}}=514.5 \mathrm{~nm}, 50 \times$ objective, numerical aperture of 0.5 leading to a laser focus diameter of $2.5 \mu \mathrm{m}$, resolution $\approx 1 \mathrm{~cm}^{-1}$ ). The laser power was about $1 \mathrm{~mW}$. 


\subsection{Sorption from solution}

The sorption isotherms were determined by the solution depletion method. Different amounts of a stock solution of styrene sulfonate $\left(0.01 \mathrm{~mol} \mathrm{~L}^{-1}\right)$ were introduced into glass tubes which contain $50 \mathrm{mg}$ of carbon in a $20 \mathrm{~mL}$ aqueous solution. The solvent is either distilled water or a saline solution $\left(0.1 \mathrm{~mol} \mathrm{~L}^{-1} \mathrm{NaCl}\right)$. The $\mathrm{pH}$ of the solution was around 6.5. The tubes were stirred during the time needed to reach equilibrium. This time was determined from a preliminary kinetic study. The suspensions were then centrifuged and the concentration of styrene sulfonate was determined at the wavelength of $255 \mathrm{~nm}$ using a UV-vis spectrophotometer (Agilent). The specific excess amount sorbed by the carbons is given by:

$\mathrm{q}_{\mathrm{e}}=\left(\mathrm{C}_{\mathrm{i}}-\mathrm{C}_{\mathrm{e}}\right) \frac{\mathrm{V}}{\mathrm{m}_{\mathrm{s}}}$ in $\mu \mathrm{mol} \mathrm{g}^{-1}$

where $C_{i}$ and $C_{e}$ are the initial and equilibrium concentrations $\left(\mu \mathrm{mol} \mathrm{L} \mathrm{L}^{-1}\right), \mathrm{V}$ the volume of solution (L), and $\mathrm{m}_{\mathrm{s}}$ the mass of the solid sample (grams). All sorption isotherms were determined at $298 \mathrm{~K}$.

Adsorption kinetic of styrene sulfonate $\left(\mathrm{C}_{\mathrm{i}}=100 \mu \mathrm{mol} . \mathrm{L}^{-1}\right)$ was performed by analyzing the adsorption capacity at different time intervals at $298 \mathrm{~K}$ until the adsorption equilibrium was reached.

\subsection{Microalorimetry}

Microcalorimetric measurements were carried out with a Tian-Calvet type microcalorimeter in a batch procedure [24] also called titration method. The presented results concern only those in saline solution because in water the kinetics of adsorption was too slow. The experimental conditions were the same as those of adsorption isotherms. Details concerning the experimental procedure of the calorimetric experiments were described previously [25]. 
Briefly, a stock solution of the molecule was injected step by step inside the microcalorimetric cell, in which the solid was maintained in suspension by a stirrer. In the reference cell, the solvent is added to the solvent. At each step, the measured heat has a contribution of both the dilution and the sorption phenomena. The dilution contribution was measured by the same procedure but without the solid inside the cell. It was subtracted from the measured heat to get the sorption enthalpy. In this study the dilution contribution is negligible. All adsorption experiments were done at $298 \mathrm{~K}$.

To extract from the calorimetric results the adsorption contribution, the adsorption isotherm must be known in order to determine the amount of styrene sulfonate adsorbed during the calorimetric experiment. Therefore, the adsorption isotherms were measured under the same experimental conditions as those used for the calorimetric experiments. From the amount adsorbed and the thermal effect corrected from the dilution contribution, the differential molar enthalpy of adsorption, $\Delta \mathrm{h}_{\mathrm{ads}}$, was calculated and plotted as a function of coverage $\theta=\mathrm{q}_{\mathrm{e}} / \mathrm{q}_{\mathrm{m}}$ where $\mathrm{q}_{\mathrm{m}}$ is the specific amount adsorbed at saturation.

\subsection{Langmuir and Freundlich models}

The adsorption isotherm equation can be derived from the chemical equilibrium between a probe molecule $(\mathrm{P})$ and surface site $(\mathrm{S})$ following:

$$
\mathrm{S}_{(\mathrm{s})}+\mathrm{P}_{(\mathrm{aq})} \Leftrightarrow \mathrm{SP}_{(\mathrm{s})}
$$

where SP is the adsorbed species. Then applying the mass equation law, one obtains

$$
\mathrm{K}_{\mathrm{L}}=\frac{\mathrm{a}_{\mathrm{SP}}}{\mathrm{a}_{\mathrm{S}} \mathrm{a}_{\mathrm{P}}}=\frac{\gamma_{\mathrm{x}, \mathrm{SP}} \mathrm{x}_{\mathrm{SP}}}{\left(\gamma_{\mathrm{x}, \mathrm{S}} \mathrm{x}_{\mathrm{S}}\right)\left(\gamma_{\mathrm{C}, \mathrm{P}} \mathrm{C}_{\mathrm{e}} / \mathrm{C}^{\circ}\right)}
$$


where $a_{i}$ is the activity of the component $i, \gamma_{i}$ is the activity coefficient, $x_{i}$ is the molar fraction, $\mathrm{C}_{\mathrm{e}}$ is the concentration of probe molecule at equilibrium (in $\mathrm{mol} \mathrm{L}^{-1}$ ) and $\mathrm{C}^{\circ}$ is the reference concentration, $\mathrm{C}^{\circ}=1 \mathrm{~mol} \mathrm{~L}^{-1}$. Assuming ideal conditions both at the surface and in dilute bulk solution we may omit the term including the activity coefficients. If we additionally introduce $\mathrm{x}_{\mathrm{S}}=1-\mathrm{x}_{\mathrm{SP}}$

the equilibrium constant becomes

$\mathrm{K}_{\mathrm{L}}=\left(\frac{\mathrm{x}_{\mathrm{SP}}}{1-\mathrm{x}_{\mathrm{SP}}} \frac{1}{\mathrm{C}_{\mathrm{e}} / \mathrm{C}^{\circ}}\right)$

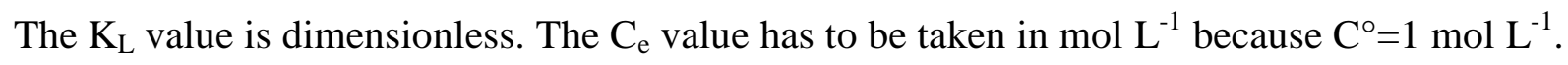
$\mathrm{C}^{\circ}$ is not written in the next part.

Rearrangement gives

$\mathrm{x}_{\mathrm{SP}}=\frac{\mathrm{K}_{\mathrm{L}} \mathrm{C}_{\mathrm{e}}}{1+\mathrm{K}_{\mathrm{L}} \mathrm{C}_{\mathrm{e}}}$

The molar fraction $\mathrm{x}_{\mathrm{SP}}$ can be expressed as:

$$
\mathrm{x}_{\mathrm{SP}}=\frac{\mathrm{n}_{\mathrm{SP}}}{\sum_{\mathrm{i}} \mathrm{n}_{\mathrm{SP}}}=\frac{\mathrm{n}_{\mathrm{SP}}}{\left(\mathrm{n}_{\mathrm{SP}}\right)_{\mathrm{m}}}=\frac{\mathrm{q}_{\mathrm{e}}}{\mathrm{q}_{\mathrm{m}}}=\theta
$$

with $\mathrm{q}_{\mathrm{e}}=\mathrm{n}_{\mathrm{SP}} / \mathrm{m}_{\mathrm{s}}$ and $\mathrm{q}_{\mathrm{m}}=\left(\mathrm{n}_{\mathrm{SP}}\right)_{\mathrm{m}} / \mathrm{m}_{\mathrm{s}}$ where $\mathrm{n}_{\mathrm{SP}}$ is the mole of solute adsorbed on the surface at equilibrium, $\left(\mathrm{n}_{\mathrm{SP}}\right)_{\mathrm{m}}$ is the maximum of mole of solute absorbed on the surface, $\mathrm{m}_{\mathrm{s}}$ is the mass of the solid, $\mathrm{q}_{\mathrm{e}}$ is the equilibrium concentration of adsorbate on the solid phase, $\mathrm{q}_{\mathrm{m}}$ is the maximal concentration of adsorbate on the solid phase, corresponding to a complete coverage of the adsorption active sites. 
The Langmuir equation widely used in the sorption of sorbate into single homogeneous sites is thus [21]

$$
q_{e}=\frac{q_{m} K_{L} C_{e}}{1+K_{L} C_{e}}
$$

here $\mathrm{q}_{\mathrm{e}}$ and $\mathrm{q}_{\mathrm{m}}$ have the same unit (here $\mu \operatorname{molg}^{-1}$ ), $\mathrm{C}_{\mathrm{e}}$ has to be taken in $\mathrm{mol} \mathrm{L}^{-1}$ and $\mathrm{K}_{\mathrm{L}}$ is thus dimensionless.

However, in many adsorption systems, it is not possible to interpret the process by means of a single adsorption process, instead, it is necessary to consider that more than one adsorption site is involved in the whole process. A method to analyse the experimental results of adsorption processes characterized by a two steps adsorption isotherm is based on a double Langmuir equation which is the sum of two Langmuirian equations:

$\mathrm{q}_{\mathrm{e}}=\frac{\mathrm{q}_{\mathrm{m}, 1} \mathrm{~K}_{\mathrm{L}, 1} \mathrm{C}_{\mathrm{e}}}{1+\mathrm{K}_{\mathrm{L}, 1} \mathrm{C}_{\mathrm{e}}}+\frac{\mathrm{q}_{\mathrm{m}, 2} \mathrm{~K}_{\mathrm{L}, 2} \mathrm{C}_{\mathrm{e}}}{1+\mathrm{K}_{\mathrm{L}, 2} \mathrm{C}_{\mathrm{e}}}$

The empirical Freundlich equation is expressed as [4]:

$\mathrm{q}_{\mathrm{e}}=\mathrm{K}_{\mathrm{F}} \mathrm{C}_{\mathrm{e}}{ }^{1 / \mathrm{n}}$

$\mathrm{K}_{\mathrm{F}}$ the Freundlich constant for a heterogeneous adsorbent and $\mathrm{n}$ are related to the magnitude of the adsorption driving force and to the adsorbent site energy distribution, respectively. This method allowed us to evaluate the maximum amount adsorbed $\left(\mathrm{q}_{\mathrm{m}, \mathrm{i}}\right)$ and the free energy of adsorption $\left(\Delta \mathrm{G}_{\mathrm{ads}, \mathrm{i}}\right)$ associated to each of the adsorption processes for a given solid-liquid 
system. To validate the analysis a microcalorimetric study was performed. The determination of adsorption enthalpies indeed enables often to map the distribution energy of sites and to validate or not the assumptions of the used models [26, 27].

\subsection{Sorption kinetic models}

When a solute adsorbs from solution onto a porous adsorbent, three types of mechanisms are generally proposed, which are: (i) film diffusion, which involves the movement of adsorbate molecules from the bulk towards the external surface of the adsorbent (ii) particle diffusion, where the adsorbate molecules move inside the adsorbent particles through the porous network and (iii) sorption of the adsorbate molecules on the pore walls of the adsorbent. The adsorption process is considered diffusion controlled if steps (i) and (ii) are much slower than step (iii), and reaction controlled if the opposite is true. In cases where post-adsorption conformational changes or electrostatic interactions are significant, a reaction controlled model has been proposed [28]. Electrostatic interactions contribute to the energy barrier. Adsorption-desorption models involving both diffusion and energy barriers have been proposed in the literature, but they involve a large number of adjustable parameters [29]. The kinetics of adsorption and desorption is thus described by diffusive and energy barrier controlled models.

\subsubsection{Diffusion controlled adsorption}

To identify the importance of diffusion in the sorption process, the amount of solute sorbed $\left(\mathrm{q}_{\mathrm{t}}\right)$ is plotted as a function of the square root of time $\left(\mathrm{t}^{0.5}\right)$. The mathematical expression of the Weber-Morris model can be represented as follows [21]: 
$\mathrm{q}_{\mathrm{t}}=\mathrm{k}_{\mathrm{i}} \mathrm{t}^{0.5}+\mathrm{l}$

where $\mathrm{q}_{\mathrm{t}}$ is the amount of solute sorbed $\left(\mu \mathrm{mol} . \mathrm{g}^{-1}\right)$ at time $\mathrm{t}, \mathrm{k}_{\mathrm{i}}$ is intra-particle diffusion rate constant $\left(\mu \mathrm{mol} \mathrm{g}{ }^{-1} \min ^{-0.5}\right)$, and I is a constant related to the thickness of the boundary layer.

\subsubsection{Role of adsorption and desorption barriers}

When there is no instantaneous equilibrium between the bulk and surface concentrations, for instance if there are large adsorption or desorption energy barriers a more detailed description of the kinetic processes in the vicinity of the adsorbed layer is required. Various models can be used to analyze the kinetics of sorption process.

Lagergren (1898) suggested a rate equation for the sorption of solutes from a liquid solution. The kinetic equation for this model, which assume that the rate of adsorption is simply proportional to the departure from equilibrium, is [30]:

$$
\frac{d q_{t}}{d t}=k_{1}\left(q_{e}-q_{t}\right)
$$

where $\mathrm{q}_{\mathrm{t}}$ is the sorbed quantity per unit mass of sorbent at time $\mathrm{t}, \mathrm{t}$ is the solid-solution contact time (min), $\mathrm{q}_{\mathrm{e}}$ is the sorbed amount per unit mass of sorbent at equilibrium and $\mathrm{k}_{1}$ is the rate constant of first-order sorption $\left(\mathrm{min}^{-1}\right)$.

Integrating for the boundary conditions $\mathrm{t}=0$ to $\mathrm{t}=\mathrm{t}$ and $\mathrm{q}=0$ to $\mathrm{q}=\mathrm{q}_{\mathrm{e}}$ gives:

$$
\ln \left(q_{e}-q_{t}\right)=\ln q_{e}-k_{1} t
$$


A pseudo-second order kinetic model developed by Ho and McKay (1998) [31] was also used to fit the experimental data. The pseudo-second order equation is based on the sorption capacity of the solid phase and can be expressed as:

$$
\frac{d q_{t}}{d t}=k_{2}\left(q_{e}-q_{t}\right)^{2}
$$

where $\mathrm{k}_{2}$ is the reaction rate constant $\left(\mathrm{g} \mu \mathrm{mol}^{-1} \mathrm{~min}^{-1}\right)$.

Separating the variables in this equation, integrating for the boundary conditions $t=0$ to $t=t$ and $\mathrm{q}=0$ to $\mathrm{q}=\mathrm{q}_{\mathrm{e}}$, and rearranging the terms, the following linear form is obtained:

$$
\frac{t}{q_{t}}=\frac{1}{k_{2} q_{e}^{2}}+\frac{1}{q_{e}} t
$$

The conditions for using first- or second-order models, and the real meaning of rate coefficients have been discussed by Azizian (2004) [32] through a theoretical analysis. Azizian [32] considers the adsorption and desorption of probe $(\mathrm{P})$ in solution by using equation 2:

$$
\mathrm{S}_{(\mathrm{s})}+\mathrm{P}_{(\mathrm{aq})} \underset{\mathrm{k}_{\mathrm{d}}}{\stackrel{\mathrm{k}_{\mathrm{a}}}{\longleftrightarrow}} \mathrm{SP}_{(\mathrm{s})}
$$

where $k_{a}$ and $k_{d}$ are the adsorption and desorption rate constants. In order to be homogeneous with the thermodynamic study (part 2.5) the activity or the molar fraction of the components were used instead of the concentration to obtain the general equation:

$$
\begin{aligned}
& \frac{\mathrm{da}_{\mathrm{SP}}}{\mathrm{dt}}=\mathrm{k}_{\mathrm{a}} \mathrm{a}_{\mathrm{S}} \mathrm{a}_{\mathrm{P}}-\mathrm{k}_{\mathrm{d}} \mathrm{a}_{\mathrm{SP}} \\
& \frac{\mathrm{dx}_{\mathrm{SP}}}{\mathrm{dt}}=\mathrm{k}_{\mathrm{a}} \mathrm{x}_{\mathrm{S}} \mathrm{x}_{\mathrm{P}}-\mathrm{k}_{\mathrm{d}} \mathrm{x}_{\mathrm{SP}}
\end{aligned}
$$

By using equations (1), (4) and (7) one obtains: 
$\frac{\mathrm{d} \theta}{\mathrm{dt}}=\mathrm{k}_{\mathrm{a}} \frac{\mathrm{C}}{\mathrm{C}^{\circ}}(1-\theta)-\mathrm{k}_{\mathrm{d}} \theta=\frac{\mathrm{k}_{\mathrm{a}}}{\mathrm{C}^{\circ}}\left(\mathrm{C}_{\mathrm{i}}-\beta \theta\right)(1-\theta)-\mathrm{k}_{\mathrm{d}} \theta$

where $\mathrm{C}$ is the molar concentration of solute at any time $\mathrm{t}$ and $\beta=\frac{\mathrm{m}_{\mathrm{s}} \mathrm{q}_{\mathrm{m}}}{\mathrm{V}}$. Equation 18 is similar to the general equation given by Azizian [32] which use concentration instead of molar fraction. In our case both $\mathrm{k}_{\mathrm{a}}$ and $\mathrm{k}_{\mathrm{d}}$ are in $\min ^{-1}$ and the concentrations of the components have to be taken in mol. $\mathrm{L}^{-1}$ because concentrations are divided by $\mathrm{C}^{\circ}=1 \mathrm{~mol} \mathrm{~L} \mathrm{~L}^{-1}$. $\mathrm{C}^{\circ}$ in not written in the next part.

At equilibrium $\frac{d \theta}{d t}=0$ and by using Langmuir equation the equilibrium constant $K_{L}$ is:

$$
\mathrm{K}_{\mathrm{L}}=\frac{\mathrm{k}_{\mathrm{a}}}{\mathrm{k}_{\mathrm{d}}}
$$

If the experimental condition be such that the initial concentration of solute $\left(\mathrm{C}_{\mathrm{i}}\right)$ is very high compared to $\beta \theta$ (i.e. $\mathrm{C}_{\mathrm{i}}>>\beta \theta$ ), then one can ignore the $\beta \theta$ term in eq. 18 , and the integration of the general equation (eq. 18) leads to the first order model [32]. The constant $\mathrm{k}_{1}$ given by the first order model is in fact a combination of adsorption $\left(\mathrm{k}_{\mathrm{a}}\right)$ and desorption $\left(\mathrm{k}_{\mathrm{d}}\right)$ constants:

$$
\mathrm{k}_{1}=\mathrm{k}_{\mathrm{a}} \mathrm{C}_{\mathrm{i}}+\mathrm{k}_{\mathrm{d}}
$$

If the initial concentration of solute is not too high for the $\beta \theta$ term $_{2}$ the general equation is integrated and the second order model given by eq 15 is obtained. The integration of eq 18 is given in details in Azizian 2004 [32]. $\mathrm{k}_{2}$ is a complex function of the initial concentration of solute. The adsorption constant $\mathrm{k}_{\mathrm{a}}$ could be calculated according to

$$
\mathrm{k}_{\mathrm{a}}=\frac{2 \mathrm{q}_{\mathrm{e}} \mathrm{k}_{2}}{\left(\beta+\mathrm{C}_{\mathrm{i}}+1 / \mathrm{K}_{\mathrm{L}}\right)+\sqrt{\left(\beta+\mathrm{C}_{\mathrm{i}}+1 / \mathrm{K}_{\mathrm{L}}\right)^{2}-4 \mathrm{C}_{\mathrm{i}} \beta}}
$$

where $\mathrm{K}_{\mathrm{L}}$ is the Langmuir constant which is calculated from the adsorption isotherm and $\beta$ and $\mathrm{C}_{\mathrm{i}}$ have to be taken in $\mathrm{mol} \mathrm{L}^{-1}$.

The desorption constant $\mathrm{k}_{\mathrm{d}}$ is calculated from equation 19. 


\section{Results and discussion}

\subsection{Characterization of the carbons}

Fig. 1 shows the nitrogen adsorption/desorption isotherms at $77 \mathrm{~K}$ of the carbons. The mesoporous carbon exhibit an isotherm of type IV with a hysteresis loop due to capillary condensation. The shape of adsorption isotherms of the carbon fibers might be considered as being type I with a sharp adsorption uptake in low relative pressure region, which is typical of microporous materials. In addition the absence of hysteresis loop indicate the absence of mesopores. Table 2 lists the textural properties indicating the pore structure of the samples. Mesopore size distribution from DFT method and micropore size distribution from QSDFT model are shown in figure $2 \mathrm{a}$ and $2 \mathrm{~b}$ respectively. The average pore size of $\mathrm{MC}$ is around 33 $\mathrm{nm}$. The carbon fiber A5 has most of its pores sizes below 1nm. The carbon fiber A20 has a bimodal micropore distribution with a sharp peak around $0.75 \mathrm{~nm}$ and a broad distribution from 1 to $2 \mathrm{~nm}$ as shown in fig. $2 \mathrm{~b}$.

The Raman spectra of ACFs and MC given in fig. 3 shows the typical feature of carbon materials with two bands around $1350 \mathrm{~cm}^{-1}$ (D band) and $1580 \mathrm{~cm}^{-1}$ (G band) [33]. The D band is characteristic for the defects and disordered carbon and the $\mathrm{G}$ band is attributed to the ordered graphitic crystallites of carbon. The ratios between the intensities of D band and G band are comparable around 0.8-0.9 for ACFs and $\mathrm{MC}$ indicating that both carbons have defects and disordered carbon. Compared with the weak D and G bands of MC, ACFs shows the overlapping of $\mathrm{D}$ band and $\mathrm{G}$ band, and the peak strengths of $\mathrm{D}$ and $\mathrm{G}$ bands are comparable, indicative of more amorphous carbons on the surface of ACFs. The 
amorphization is also confirmed by the position of the $\mathrm{G}$ band which moves from $1580 \mathrm{~cm}^{-1}$ (graphite) to $1610 \mathrm{~cm}^{-1}$ (nanocrystalline graphite) [33].

\subsection{Sorption kinetics}

Specific adsorbed amounts of styrene sulfonate on mesoporous carbon and carbon fibers A5 and A20 at different contact times in water are presented in figure 4. For the fiber A20 the sorbed amounts increased quickly until equilibrium within 10 min of solid-solution contact time. In contrast much slower kinetics are observed with the mesoporous carbon and the carbon fiber A5. The equilibrium is obtained after one week. Plots of the adsorption of styrene sulfonate on carbon fiber (A5) amount versus time are shown in figure 5 in the absence or the presence of a saline solution $\left(\mathrm{NaCl}\left(0.1 \mathrm{~mol} \cdot \mathrm{L}^{-1}\right)\right)$. For all adsorbents the kinetic of adsorption is much faster in presence of a saline solution. Previous research has indicated that pore diffusion can be the rate-controlling step if $\mathrm{q}_{\mathrm{t}}$ is linearly correlated with $\mathrm{t}^{0.5}$ and the regression line passes through the origin $[12,14]$. In water, for ACFs and $\mathrm{MC}$ the results show that $\mathrm{q}_{\mathrm{t}}$ are not linearly correlated with $\mathrm{t}^{0.5}$, suggesting that the diffusion in the pores is not the ratecontrolling step for the sorption kinetics. The plots are not shown because diffusion is not the rate limiting step. Moreover the mesoporous carbon has a much greater pore volume and larger pore size than the ACFs (Table 2) and thus the pore diffusion should be faster in the MC than in the ACFs [34]. However the kinetic of adsorption is faster with the ACFs further suggesting that the pore-diffusion process cannot be the rate-controlling step for the sorption kinetics of styrene sulfonate onto carbons. The rate limiting step is due to energy barriers including electrostatic repulsion between styrene sulfonate and the carbons which are both negatively charged. The electrostatic repulsion is screened at high ionic strength as shown in figure 4 leading to faster kinetics. By salt addition the electrical barrier could be lowered by 
reduction of the zeta potential at the surface $[29,35,36]$. This point is developed in the next part.

Data were analyzed by fitting the data by the pseudo-first- and pseudo-second-order models. These models are the most frequently used to establish kinetic parameters of sorption process for different solutes on different sorbents. Kinetic parameters are presented in table 3, where only data by the second-order model are presented. The higher value of $\mathrm{R}^{2}$, the lower standard error for each parameter and the accuracy to predict $\mathrm{q}_{\mathrm{e}}$ were indeed used as criterion to define the most suitable model to describe sorption kinetics of styrene sulfonate. The $\mathrm{R}^{2}$ values for the pseudo-first-order model are lower than 0.9 for all adsorbents studied in water and in the saline solution. Furthermore, the $\mathrm{q}_{\mathrm{e}}$ experimental value does not agree with the calculated one. Higher values for $\mathrm{R}^{2}$ were obtained for the pseudo-second-order model $(>0.99)$ and the predicted values of $\mathrm{q}_{\mathrm{e}}$ agree well with the experimental values (see table 3 ). The better fit of the pseudo-second-order model might be expected because of the low initial concentration of styrene sulfonate used in the kinetic experiments for all adsorbents as explained by Azizian [32]. So, experimental data for styrene sulfonate are accurately described by this model at all time intervals (Figs 4 and 5). The $\mathrm{k}_{\mathrm{a}}$ and $\mathrm{k}_{\mathrm{d}}$ constants are calculated according to equations 21 and 19 by using the $\mathrm{K}_{\mathrm{L}}$ values obtained experimentally. The results are given in table 3 . Rate constant values showed the fastest adsorption kinetics for the fiber A20 in both water and saline solution (table 3). For the ACF (A5) the slower adsorption rate compared to the ACF (A20) should be ascribed to the steric effect, i.e., the adsorbate molecule has difficulties in moving within pores with size not large enough. In fact the molecular dimension of styrene sulfonate and the average pore size of ACF (A5) are very close to each other. At the start, the movement of the styrene sulfonate is restricted by the pore structure and with the proceeding of the adsorption, adsorbed molecules may occupy the pore entrance and delay the adsorption of the following ones. The adsorption rate of styrene sulfonate on MC is slower than on the 
ACF probably due to the fact that the attractive forces between styrene sulfonate and the carbon surfaces could be different as explained in the next part.

\subsection{Adsorption Thermodynamics}

The isotherms of styrene sulfonate adsorption from aqueous solutions onto the carbons at 298 $\mathrm{K}$ are plotted in figure 5 without or with $\mathrm{NaCl}\left(0.1\right.$ mol. $\left.\mathrm{L}^{-1}\right)$, expressed as the amount of styrene sulfonate adsorbed per $\mathrm{g}$ of adsorbent $\left(\mathrm{q}_{\mathrm{e}}\right)$ vs the equilibrium concentration $\left(\mathrm{C}_{\mathrm{e}}\right)$. As described above, the contact time necessary to reach equilibrium varied between 5 min and 1 week depending on the samples. These isotherms show similar behaviour, i.e., a strong affinity of the styrene sulfonate molecules for the surface, as evidenced by the initial slope. For each isotherm, the equilibrium adsorption amount of styrene sulfonate onto carbons increases with increasing equilibrium concentration. For all carbons the amount adsorbed increases in the presence of a saline solution at all sulfonate concentrations.

The isotherms equilibrium data were analyzed with the well-known Langmuir and Freundlich models (figs 7-8). All the isotherms were well fitted with the Langmuir or double Langmuir models. The parameters of the models are listed in table 4. The adsorption of styrene sulfonate onto carbon fiber A5 and mesoporous carbon MC in water and in a saline solution can well be fitted by the Langmuir model as shown in figures 7-and 8. Langmuir model assumes uniform energies of adsorption onto the surface of adsorbent and no interaction between adsorbed molecules. The data of some studied systems were not well fitted with Langmuir equation, indicating that surface energies were not uniform: for example, the Langmuir model does not describe the experimental results in the case of the carbon fiber A20 in both water and saline solutions. The results obtained with the fiber A20 are well fitted with the double Langmuir 
model suggesting that there are two types of adsorption sites. Those results are confirmed by the calorimetric study as shown in the next part. The maximum adsorption capacity of the adsorbents, $\mathrm{q}_{\mathrm{m}}$, was obtained from the Langmuir and the double Langmuir equation. In the double Langmuir model $\mathrm{q}_{\mathrm{m}}$ is the addition of the monolayer capacity evaluated for the two sites $\mathrm{q}_{\mathrm{m}, 1}$ and $\mathrm{q}_{\mathrm{m}, 2}$. The $\mathrm{q}_{\mathrm{m}, \mathrm{i}}$ value corresponds to the transition from a regime where the adsorption mainly occurs on the highest energetic sites to a regime where the adsorption occurs on the sites with the lowest energy. The highest $\mathrm{q}_{\mathrm{m}}$ values are obtained for the carbon fibers in a saline solution.

Compared with the other adsorbents, the maximum adsorption capacity of styrene sulfonate by ACFs is higher than that on multi-walled carbon nanotubes and activated carbon powders where the values ranged between 20 and $218 \mu$ mol.g ${ }^{-1}$ in a 0.01 mol. $\mathrm{L}^{-1} \mathrm{NaCl}$ solution ( $\mathrm{pH} 7$ ) [21].

Effect of ionic strength on styrene sulfonate adsorption onto carbons

The kinetic of adsorption of styrene sulfonate onto carbons is much faster (see table 3 ) and the amount adsorbed increases in presence of $\mathrm{NaCl}\left(0.1 \mathrm{~mol} . \mathrm{L}^{-1}\right)$ for all studied adsorbents. These results show that non-electrostatic interactions are involved between the solute and the surface since at high $\mathrm{NaCl}$ concentration the electrostatic part of the interaction is screened. Experimental data supported that sodium chloride in the solution facilitated styrene sulfonate adsorption on materials like polystyrenes [37] and alumina [38] for example.

The surface coverage is an approximate value and is just taken as a reference parameter to compare the immobilization performance combined with the support characteristics. It is calculated by assuming the average molecular dimension for the styrene sulfonate molecule as $1 * 0.45 \mathrm{~nm}$. Because the orientations of the immobilized styrene sulfonate are unknown, the 
surface area covered by one molecule is calculated using the smallest and largest values of the molecule dimensions generating a rectangle at the surface of the adsorbents. Consequently one molecule occupies $0.45 \mathrm{~nm}^{2}$, then the surface coverage for one monolayer of styrene sulfonate is around $3.7 \mu \mathrm{mol} . \mathrm{m}^{-2}$. The calculated value is only an approximation, because the surface area accessible to $\mathrm{N}_{2}$ molecules is greater than the actual surface area accessible to other molecules with a larger size. Nyazi et al (2005) [39] studied the adsorption of herbicides $\left(0.63 \mathrm{~nm}^{2}\right)$ onto non porous carbon black and found similar values around $3 \mu \mathrm{mol} . \mathrm{m}^{-2}$ for the formation of a monolayer of herbicide on the carbon surface. The ratio between the maximal amount adsorbed $\left(\mathrm{q}_{\mathrm{m}}\right)$ and the theoretical value calculated for the formation of one monolayer $\left(3.7 \mu \mathrm{mol} . \mathrm{m}^{-2}\right)$ ranged between 10 and $20 \%$ for the studied carbons in water and in a saline solution. The low affinity of styrene sulfonate for the carbons at a $\mathrm{pH}$ around 6.5 could be due to electrostatic repulsion between the surface and the molecule. The surface charge is a function of $\mathrm{pH}$. The $\mathrm{pH}$ with which the net charge of the solid surface is zero is referred to as the zero point of charge $\left(\mathrm{pH}_{\mathrm{zpc}}\right)$. Below the $\mathrm{pH}_{\mathrm{zpc}}$, the surface has a net positive charge; above $\mathrm{pH}_{\mathrm{zpc}}$, the surface has a net negative charge. Values of the $\mathrm{pH}_{\mathrm{pzc}}$ of nonpolar materials prepared under exclusion of oxygen and the water saturated with hydrogen were reported variously at near pH 0 and pH 0.5. Lau et al. (1986) [40] demonstrated that the equilibrium graphite-water interface had a pzc value around $\mathrm{pH}$ 2-3 if the well-characterized graphite was allowed to come to equilibrium with air or oxygen. Lee et al., 2002 [41] found that the $\mathrm{pH}_{\mathrm{zpc}}$ of carbon fiber was around 3. Thus at $\mathrm{pH} 6.5$ both styrene sulfonate $\left(\mathrm{pK}_{\mathrm{a}}=1\right)$ and the surface of the carbons are negatively charged. Cosgrove et al. (1986) [37] studied the adsorption of polystyrene on polystyrene latex particles positively or negatively charged at different ionic strength. For the negatively charged surface no adsorption was found in zero added salt due to electrostatic repulsion. Caminati and Gabrielli (1993) [42] studied the adsorption of polystyrene sulfonate of different molecular weights onto graphitized carbon black (graphon) 
which has a highly homogeneous surface with virtually no polar groups in water. The maximum adsorption obtained is around $0.14 \mu \mathrm{mol} . \mathrm{m}^{-2}$ for the PSS $1800 \mathrm{~g} \cdot \mathrm{mol}^{-1}$ and 0.038 $\mu$ mol.m ${ }^{-2}$ for the PSS 18000 g.mol ${ }^{-1}$. The surface area per molecule is around $365 \AA^{2}$ for the PSS 1800 g.mol ${ }^{-1}$ and around $1466 \AA^{2}$ for the PSS 18000 g.mol ${ }^{-1}$ corresponding to a percentage of surface coverage respectively around 30 and $34 \%$.

The interaction between the molecule and the surface is the sum of two antagonistic forces: electrical repulsion and attractive forces between hydrophobic part of the molecule and the surface. This latter can be due to the so-called hydrophobic interaction (entropic contribution corresponding to the liberation of water molecules when two hydrophobic domain are put into contact) but also to $\pi$ - $\pi$ dispersion interaction between styrene and graphene patches on the surface.- From Raman spectra we conclude that ACFs have more graphitic defects and are more amorphous than MC. Defected sites are generally regarded as high surface energy sites on graphene nanosheets [43]; thus, the presence of more defected sites on ACFs could explain its higher adsorption capacity for styrene sulfonate. Hydrogen bonding between styrene sulfonate and oxygen functional surface groups should be negligible because styrene sulfonate and surfaces are both negatively charged.

Adsorption thermodynamics

From the constants of adsorption (table 4) it is possible to evaluate the standard molar adsorption free energy $\Delta_{\text {ads }} G_{\mathrm{m}}^{\circ}\left(\mathrm{kJ} \cdot \mathrm{mol}^{-1}\right)$ according to the equation:

$\Delta_{\text {ads }} \mathrm{G}_{\mathrm{m}}^{\circ}=-\mathrm{RT} \ln \mathrm{K}_{\mathrm{L}}$ 
where $\mathrm{K}_{\mathrm{L}}$ is the adsorption equilibrium constant obtained with the Langmuir and the double Langmuir models, $\mathrm{R}$ is the universal gas constant, $8.314 \mathrm{~J} \mathrm{~mol}^{-1} \mathrm{~K}^{-1}$, $\mathrm{T}$ is the absolute temperature.

The $\Delta_{\text {ads }} \mathrm{G}_{\mathrm{m}}^{\circ}$ values are listed in table 4 . Negative $\Delta_{\text {ads }} \mathrm{G}_{\mathrm{m}}^{\circ}$ values are obtained in all cases, in agreement with the spontaneous nature of these adsorptions. Similar $\Delta_{\text {ads }} G_{m}^{\circ}$ values around $30 \mathrm{~kJ} . \mathrm{mol}^{-1}$ are obtained by Caminati and Gabrielli (1993) [42] who studied the adsorption of polystyrene sulfonate onto graphitized carbon black (graphon) in water.

Differential enthalpy of adsorption of styrene sulfonate onto activated carbons fibers and mesoporous carbon, $\Delta \mathrm{h}_{\mathrm{ads}}$, was determined by microcalorimetry. The variation of $-\Delta \mathrm{h}_{\mathrm{ads}}$ with the surface coverage is different for the mesoporous carbon and carbon fibers (fig. 9). The $\Delta \mathrm{h}_{\mathrm{ads}}$ values observed with the mesoporous carbon are constant (around $-30 \mathrm{~kJ} \mathrm{~mol}^{-1}$ ) over a large range of coverage. A constant differential adsorption versus coverage is often attributed to a relatively homogeneous surfaces [44,_45]. The homogeneous character of this mesoporous carbon surface is in agreement with the mainly graphitic character of the surface. For the two carbon fibers the adsorption enthalpy decreases as $\theta$ increases, but remains exothermal in the entire range of coverage studied, varying from $-80 \mathrm{~kJ}^{\mathrm{mol}} \mathrm{l}^{-1}$ to $-60 \mathrm{~kJ} \cdot \mathrm{mol}^{-1}$ for the fiber A20 and to $-15 \mathrm{~kJ} \cdot \mathrm{mol}^{-1}$ for the fiber A5. At low concentration styrene sulfonate is adsorbed on the most energetic sites of the accessible surface area and then on the lower energetic sites as the concentration in solution increases. The styrene sulfonate adsorption is progressively less energetic as the concentrations increases. At very low coverage the enthalpy of adsorption is similar on the two fibers (around $80 \mathrm{~kJ} \cdot \mathrm{mol}^{-1}$ ). The dispersion of adsorption energies is higher for A5. When the adsorption enthalpy is bellow that on the mesoporous adsorbent, it may indicates that molecules are adsorbed in very narrow pores. 
Indeed when the minimum of potential energy of adsorption is plotted as a function of pore size, it first decreases when pore size decreases (higher energies of adsorption), but then it increases when pores become very small because the repulsive part of the Lennard Jones potential may be predominant [46].

Two enthalpy regions are found over and below a value of $\theta$ around 0.4 for the carbon fiber A20. The amount of styrene sulfonate adsorbed at this coverage is $246 \mu \mathrm{mol} . \mathrm{g}^{-1}$. This value is close to the monolayer capacity found from the double Langmuir model $\mathrm{q}_{\mathrm{max}, 1}=255 \mu \mathrm{mol} \cdot \mathrm{g}^{-1}$ as given in table $4 \mathrm{~b}$. This result suggests the presence of two different steps involved in the whole adsorption process. On this assumption, each of the calorimetric regions corresponds to a discrete adsorption process, which can be described by a Langmuir equation. Those results suggest that styrene sulfonate is adsorbed on higher and lower energetic areas of the accessible surface area. This could be due to adsorption inside pores of different sizes. The carbon fiber A20 has effectively a bimodal micropore distribution.

By analysing the behaviour of the mesoporous carbon and the fibers at very low coverage it can be noted that the heat of adsorption of the fibers is about twice that of the mesoporous carbon. This could be explained by the molecule to pore size ratio which is about 0.02 for the mesoporous carbon and about $0.6-0.7$ for fibers by taking an average molecular size about $0.45 \mathrm{~nm}$ for the styrene sulfonate. In fact, if a molecule is adsorbed onto a slit-shaped pore whose width is close to the solute size, it interacts simultaneously with both of the micropores walls, leading to an adsorption enthalpy twice that for molecules adsorbed on a more open surface [47]. 


\section{Conclusions}

The adsorption of styrene sulfonate on carbon fibers and mesoporous carbon at different ionic strength was studied. It appears that the repulsive interaction between styrene sulfonate and carbon surfaces both negatively charged is the rate limiting step in the adsorption processes. The Langmuir and double Langmuir equations used to model the adsorption isotherms were validated by using calorimetry.

\section{Acknowledgments}

We would like to thank Cédric Pardanaud (Aix Marseille University-CNRS, UMR 7345, PIIM) for the Raman spectra. 


\section{References}

[1] M.A. Fontecha-Camara, M.V. Lopez-Ramon, L.M. Pastrana-Martinez, C. MorenoCastilla, J. Hazard. Mater. 156 (2008) 472-477.

[2] R. Leyva-Ramos, P.E. Diaz-Flores, J. Leyva-Ramos, R.A. Femat-Flores, Carbon 45 (2007) 2280-2289.

[3] K. Li, Z. Zheng, J. Feng, J. Zhanga, X. Luoa, G. Zhaoa, X. Huanga, J. Hazard. Mater. 166 (2009) 1180-1185.

[4] Q.S. Liu, T. Zheng, P. Wang, J.P. Jiang, N. Li, Chem. Eng. J. 157 (2010) 348-356.

[5] M.V. Lopez-Ramon, M.A. Fontecha-Camara, M.A. Alvarez-Merino, C. Moreno-Castilla, Water Res. 41 (2007) 2865-2870.

[6] X. Ma, F. Zhang, J. Zhu, L. Yu, X. Liu, Bioresour. Technol. 164 (2014) 1-6.

[7] T. Kimura, H. Kanoh, T. Kanda, T. Ohkubo, Y. Hattori, Y. Higaonna, R. Denoyel, K. Kaneko, J. Phys. Chem. B 108 (2004) 14043-14048.

[8] E. Diaz, S. Ordonez, A. Vega, J. Colloid Interface Sci. 305 (2007) 7-16.

[9] F. Su, C. Lu, S. Hu, Colloids and Surfaces A: Physicochem. Eng. Aspects 353 (2010) 8391.

[10] C. Lu, F. Su, Sep. .Purif. Technol. 58 (2007) 113-121.

[11] C.H. Wu, J. Hazard. Mater. 144 (2007) 93-100.

[12] L. Wang, Y. Yao, Z. Zhang, L. Sun, W. Lu, W. Chen, H. Chen, Chem. Eng. J. 251 (2014) 348-354.

[13] S. Gotovac, C.M. Yang, Y. Hattori, K. Takahashi, H. Kanoh, K. Kaneko, J. Colloid Interface Sci. 314 (2007) 18-24. 
[14] G.C. Chen, X.Q. Shan, Y.Q. Zhou, X. Shen, H.L. Huang, S.U. Khan, J. Hazard. Mater. 169 (2009) 912-918.

[15] A. Stafiej, K. Pyrzynska, Sep. Purif. Technol. 58 (2007) 49-52.

[16] S. Shrestha, G., Son, S.H. Lee, T.G. Lee, Chemosphere 92 (2013) 1053-1061.

[17] Q. Li, V.L. Snoeyink, B.J. Mariaas, C. Campos, Water Res. 37 (2003) 773-784.

[18] A.D. Revchuk, I.H. Suffet, Water Res. 43 (2009) 3685-3692.

[19] N. Ando, Y. Matsui, R. Kurotobi, Y. Nakano, T. Matsushita, K. Ohno, Water Res. 44 (2010) 4127-4136.

[20] N. Kawasaki, K. Matsushige, K. Komatsu, A. Kohzu, F.W. Nara, F. Ogishi, M. Yahata, H. Mikami, T. Goto, A. Imai, Water Res. 45 (2011) 6240-6248.

[21] T. Li, D. Lin, L. Li, Z. Wang, F. Wu, Environ.Pollut. 186 (2014) 43-49.

[22] E.P. Barrett, L.G. Joyner, P.H. Hallenda, J. Am. Chem. Soc. 73 (1951) 373-380.

[23] A.V. Neimark, Y. Lin, P.I. Ravikovitch, M. Thommes, Carbon 47 (2009) 1617-1628.

[24] R. Denoyel, F. Giordano, J. Rouquerol, Colloids Surfaces 76 (1993) 141-148.

[25] R. Denoyel, F. Rouquerol, J. Rouquerol, J. Colloid Interface Sci. 136 (1990) 375-384.

[26] R. Denoyel, Colloids and Surfaces A: Physicochem. Eng. Aspects 205 (2002) 61-71.

[27] C.M. Gonzalez-Garcia, M.L. Gonzalez-Martin, R. Denoyel, A.M. Gallardo-Moreno, L. Labajos-Broncano, J.M. Bruque, Carbon 43 (2005) 567-572.

[28] L.J. Kimberly, C. R. O’Melia, J. Membrane Sci. 165 (2000) 31-46.

[29] Y. He, P. Yazhgur, A. Salonen, D. Langevin, Adv. Colloid Interface Sci. (2014), in press [30] S. Lagergren, Handlingar 24 (1898) 1-39.

[31] Y.S. Ho, G. McKay, G. Chem. Eng. J. 70 (1998) 115-124.

[32] S. Azizian, J. Colloid Interface Sci. 276 (2004) 47-52.

[33] A. C. Ferrari, J. Robertson, Phys. Rev. B, 61 (2000), 14095-14107

[34] V. Wernert, R. Bouchet, R. Denoyel, Anal. Chem., 82 (2010) 2668-2679. 
[35] F. MacRitchie, A.E. Alexander, J. Colloid Sci. 18 (1963) 464-469.

[36] A.W.M. de Laat, G.L.T van den Heuvel, M.R. Böhmer, Colloids and Surfaces A: Physicochem. Eng. Aspects 98 (1995) 61-71.

[37] T. Cosgrove, T.M. Obey, B. Vincent, J. Colloid Interface Sci. 111 (1986) 409-418.

[38] A.M. Blokhus, K. Djurhuus, Colloid Interface Sci. 296 (2006) 64-70.

[39] K. Nyazi, A. Baçaoui, A. Yaacoubi, H. Darmsatdt, A. Adnot , C. Roy, Carbon 43 (2005) 2215-2234.

[40] A.C. Lau, D.N. Furlong, T.W. Healy, F. Grieser, Colloids Surf. 18 (1986) 93-104.

[41] S.M. Lee, S.K. Ryu, C.H. Jung, H.J. Won, W.Z. Oh, Carbon 40 (2002) 329-334.

[42] G. Caminati, G. Gabrielli, Colloids Surf. A 70 (1993) 1-14.

[43] J. Wang, B. Chen, Chem. Eng. J. 281 (2015) 379-388

[44] R. Denoyel, G. Durand, F. Lafuma, R. Audebert, J. Colloid Interface Sci. 139 (1990) 281-290.

[45] P. Pendleton, S.H. Wong, R. Schumann, G. Levay, R. Denoyel, J. Rouquerol, Carbon 35 (1997) 1141-1149.

[46] D. H. Everett, J. C. Powl, J. Chem. Soc., Faraday Trans I, 72 (1976) 619-636.

[47] G. Gonzalez, R. Denoyel, M.L. Gonzalez-Martin, V. Gomez-Serrano, Thermochim. Acta 375 (2001) 177-185. 
List of figures

Figure 1. Nitrogen adsorption-desorption isotherms at $77 \mathrm{~K}$ on a) mesoporous carbon, b) carbon fibers

Figure 2. Pore size distribution for a) the mesoporous carbon and b) the carbon fibers A20 and A5

Figure 3. Raman spectra of MC and ACFs

Figure 4. Plot of $\mathrm{q}_{t} / \mathrm{q}_{\mathrm{e}}$ vs. time for the adsorption of styrene sulfonate onto carbon fibers A5 and A20 and onto mesoporous carbon in water $(\mathrm{T}=298 \mathrm{~K})$. The results are fitted by the pseudo-second order kinetic model

Figure 5. Plot of $\mathrm{q}_{\mathrm{t}} / \mathrm{q}_{\mathrm{e}}$ vs. time for the adsorption of styrene sulfonate onto carbon fiber (A5) ( $\mathrm{T}=298 \mathrm{~K}$ ) in water and $0.1 \mathrm{~mol} . \mathrm{L}^{-1} \mathrm{NaCl}$. The results are fitted by the pseudo-second order kinetic model

Figure 6. Adsorption isotherms of styrene sulfonate onto carbon fibers (A5 and A20) and mesoporous carbon in absence and in presence of a saline solution at $25^{\circ} \mathrm{C}$.

Figure 7. Adsorption isotherms of styrene sulfonate onto carbon fibers a) A20 and b) A5 in absence and in presence of a saline solution at $25^{\circ} \mathrm{C}$. Line fit with the Freundlich and the Langmuir and the double Langmuir equation

Figure 8. Adsorption isotherms of styrene sulfonate onto mesoporous carbon in absence and in presence of a saline solution at $25^{\circ} \mathrm{C}$. Line fit with the Freundlich and Langmuir equation

Figure 9. Differential enthalpies of adsorption of styrene sulfonate versus coverage $\theta$ onto carbon fibers A5 and A20 and onto mesoporous carbon in a saline solution $\left(\mathrm{NaCl}\right.$ 0.1 mol. $\left.\mathrm{L}^{-1}\right)$ 

a)

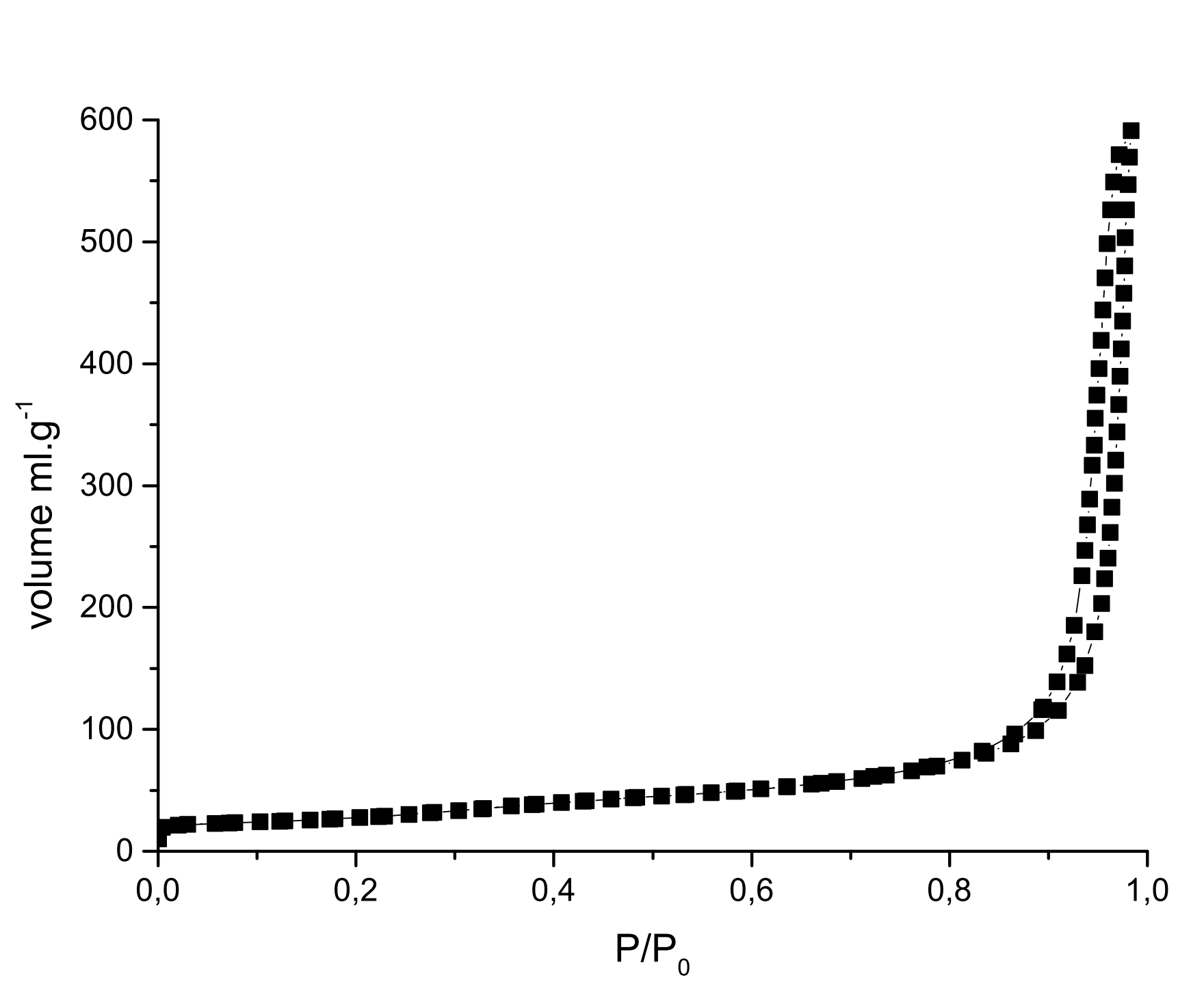

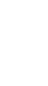

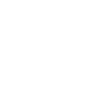


b)

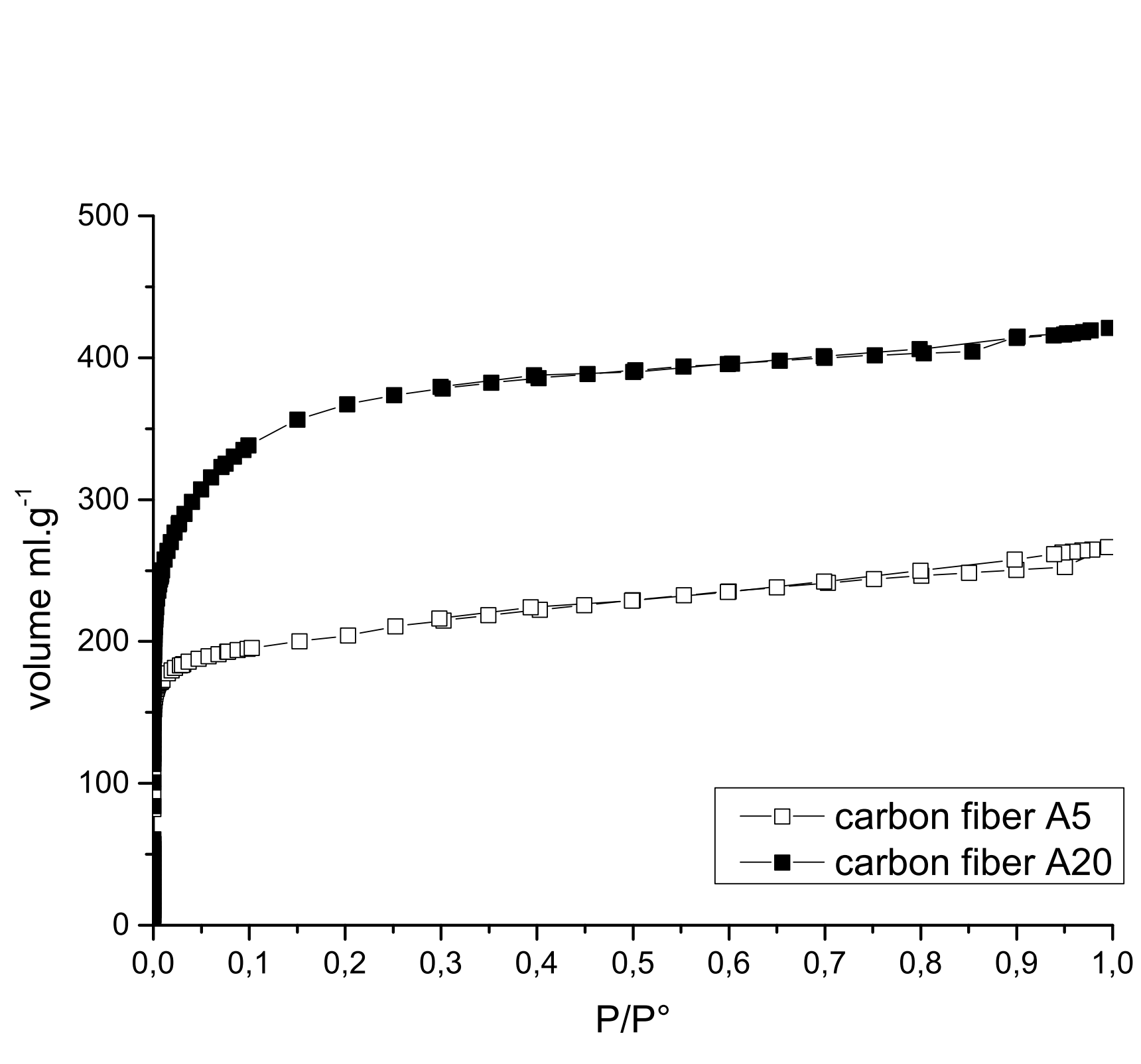

figure $1 b$

.

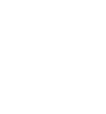




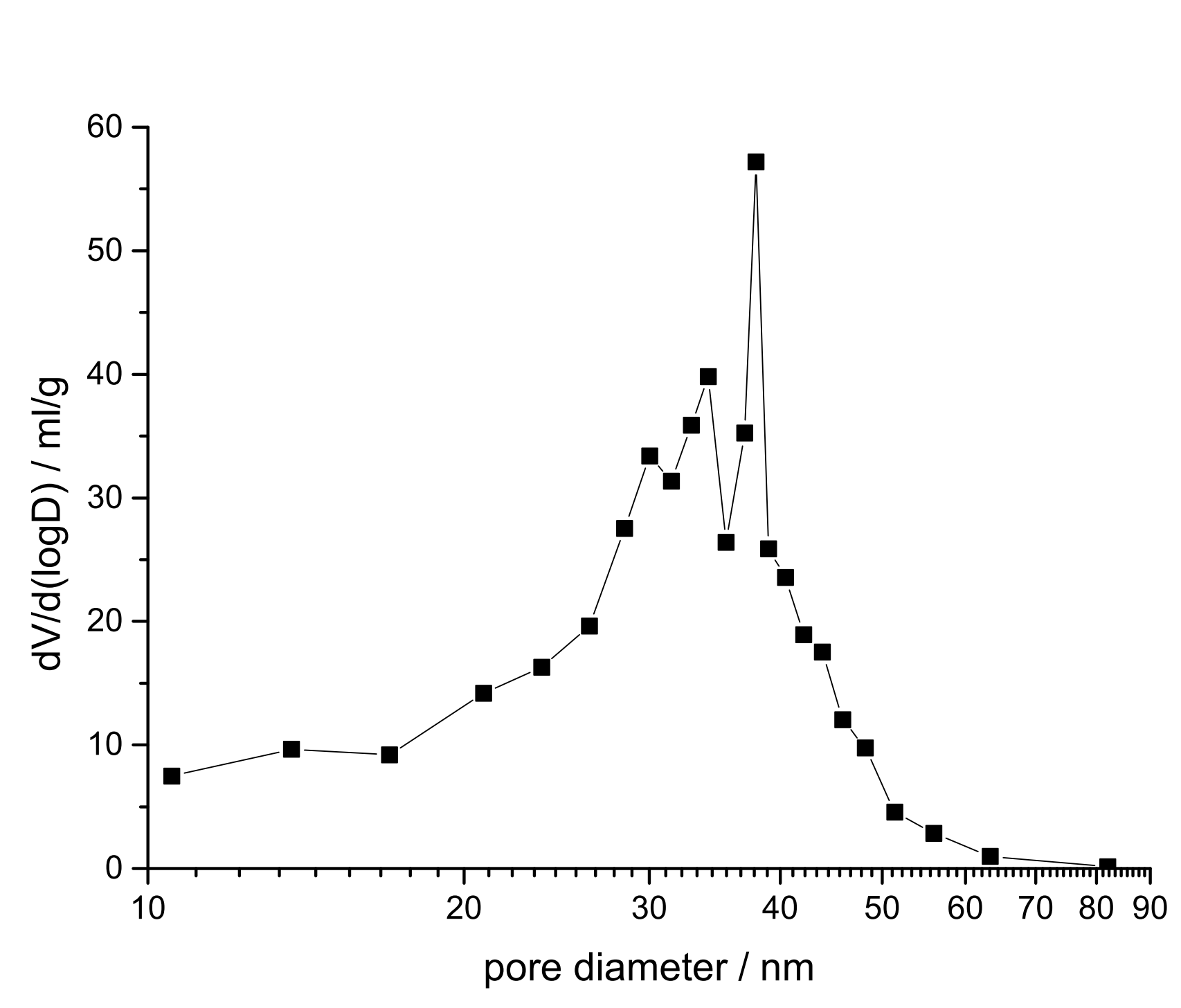

Figure 2a 


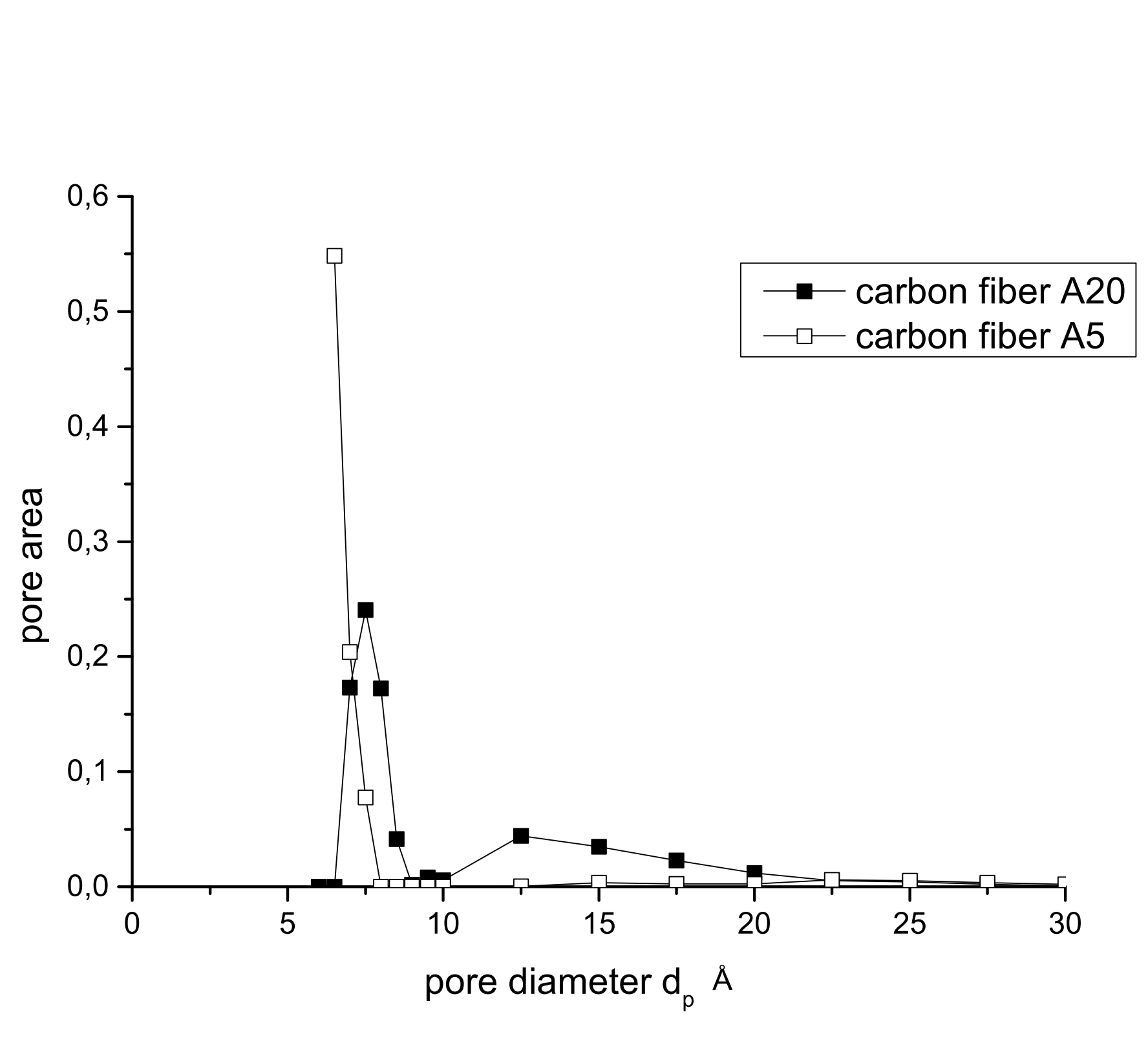

Figure $\mathbf{2 b}$

.

Figure $2 b$

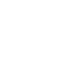

-

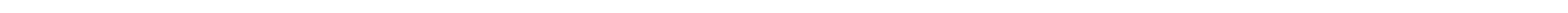


Figure 3

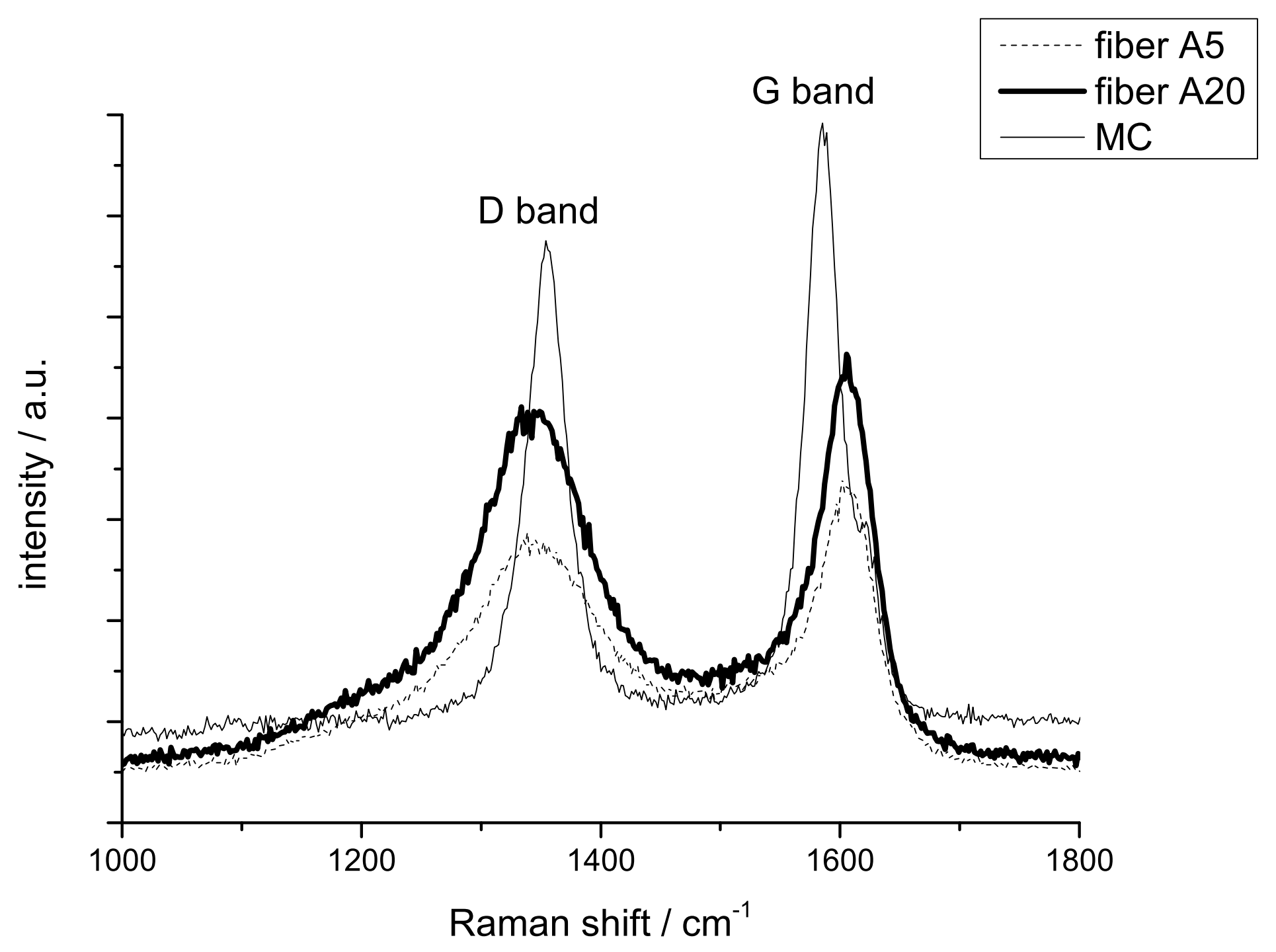




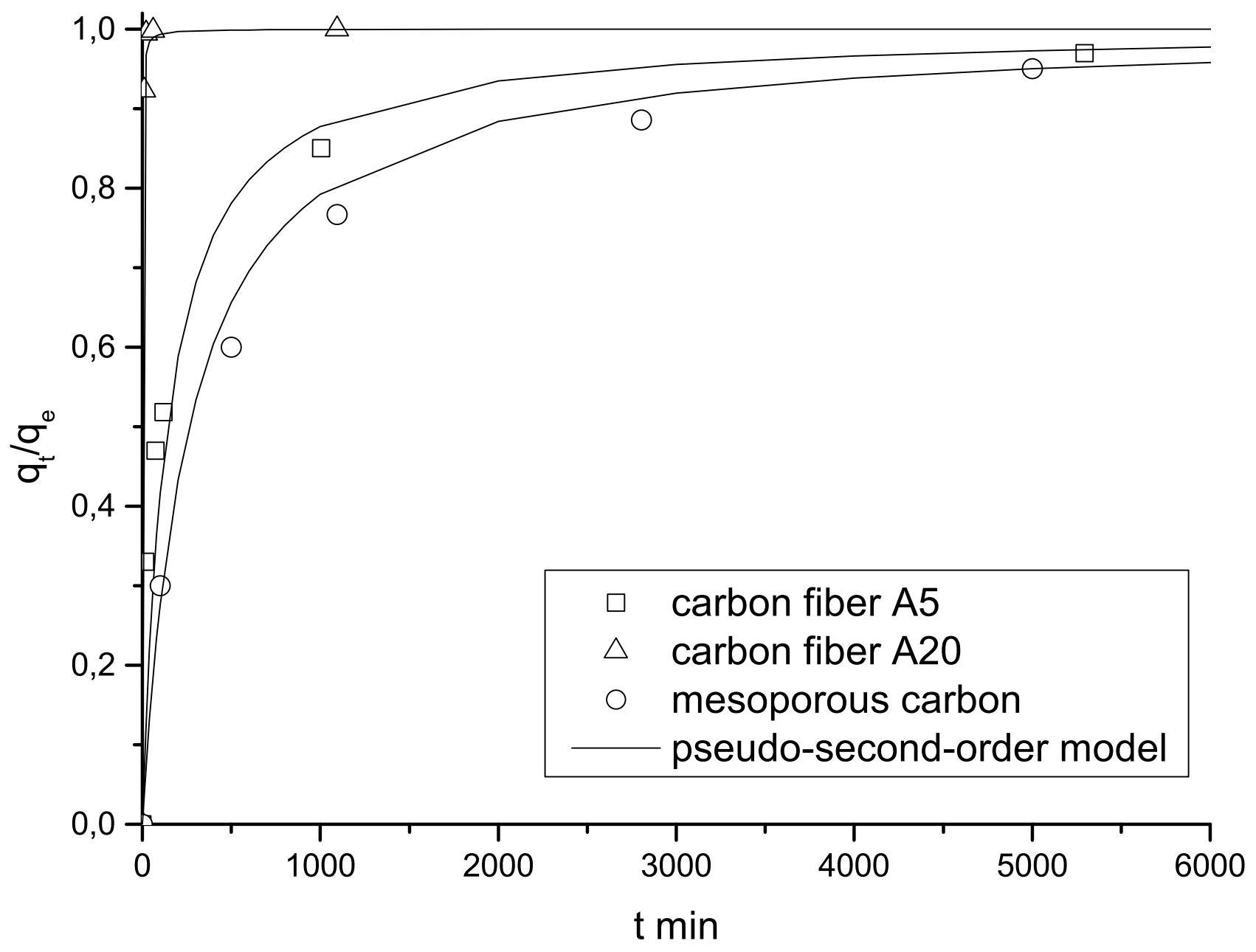




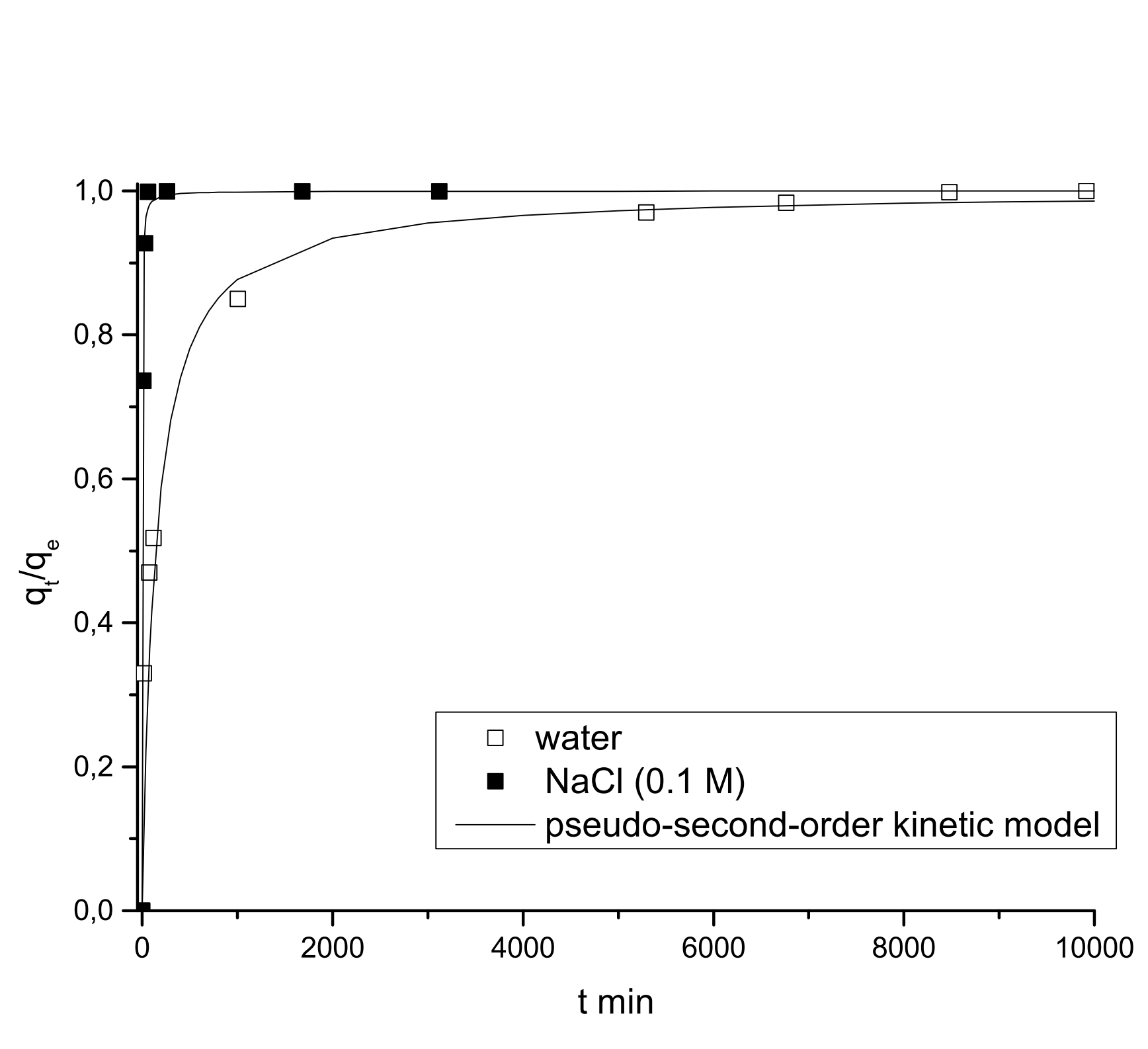

Figure 5

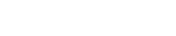

5

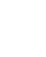

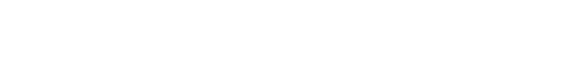

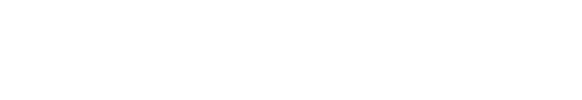




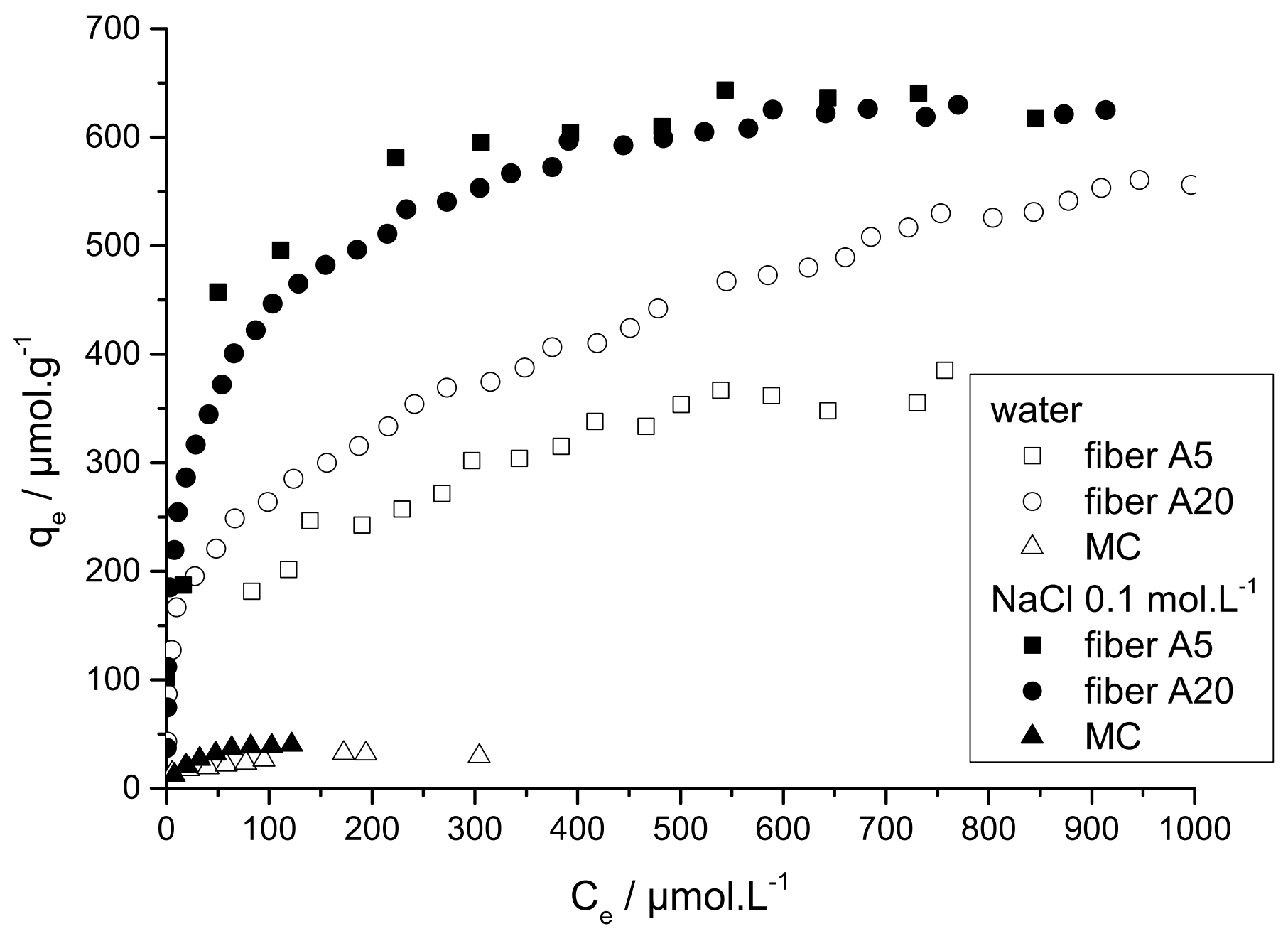




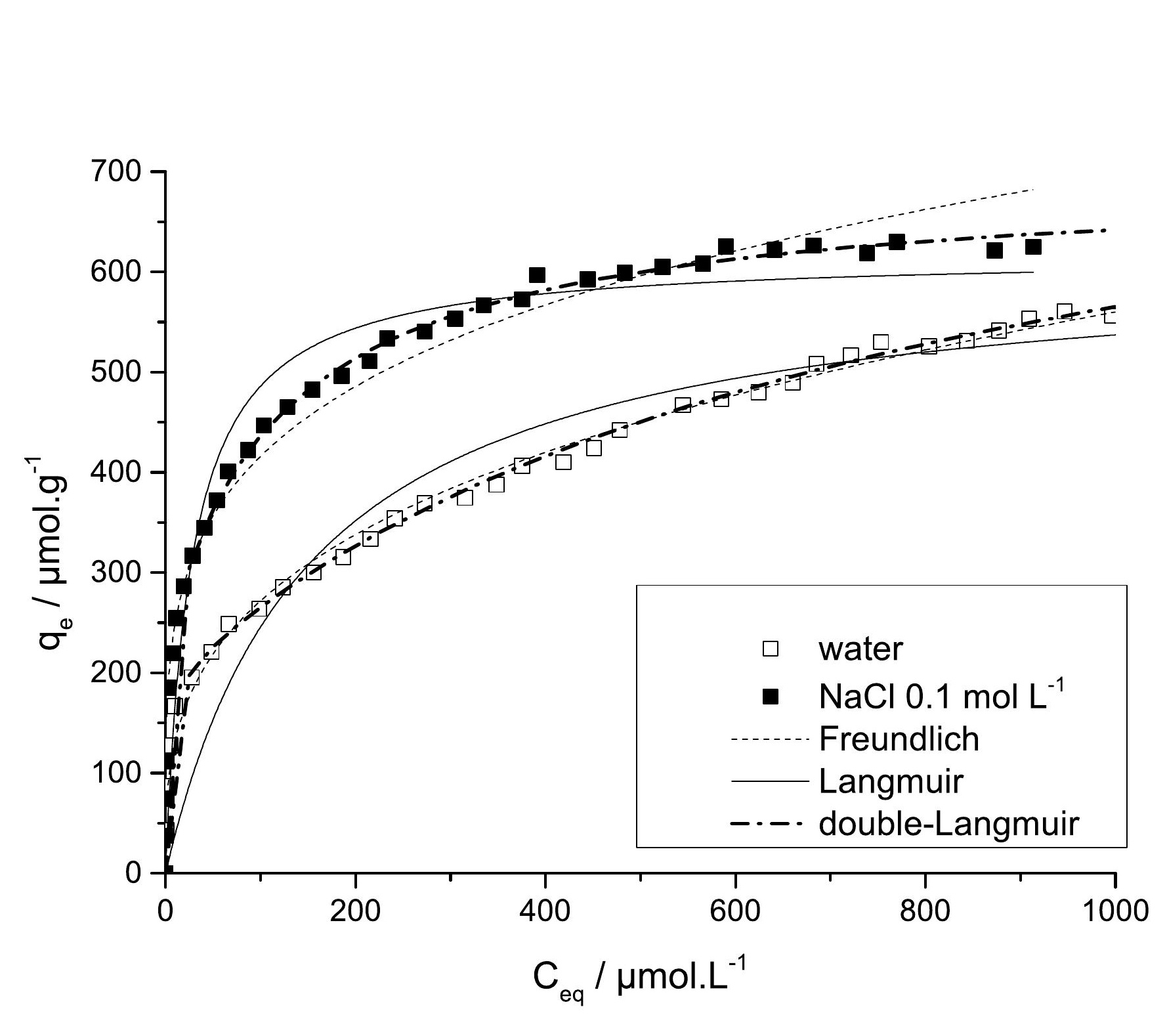

Figure 7a 


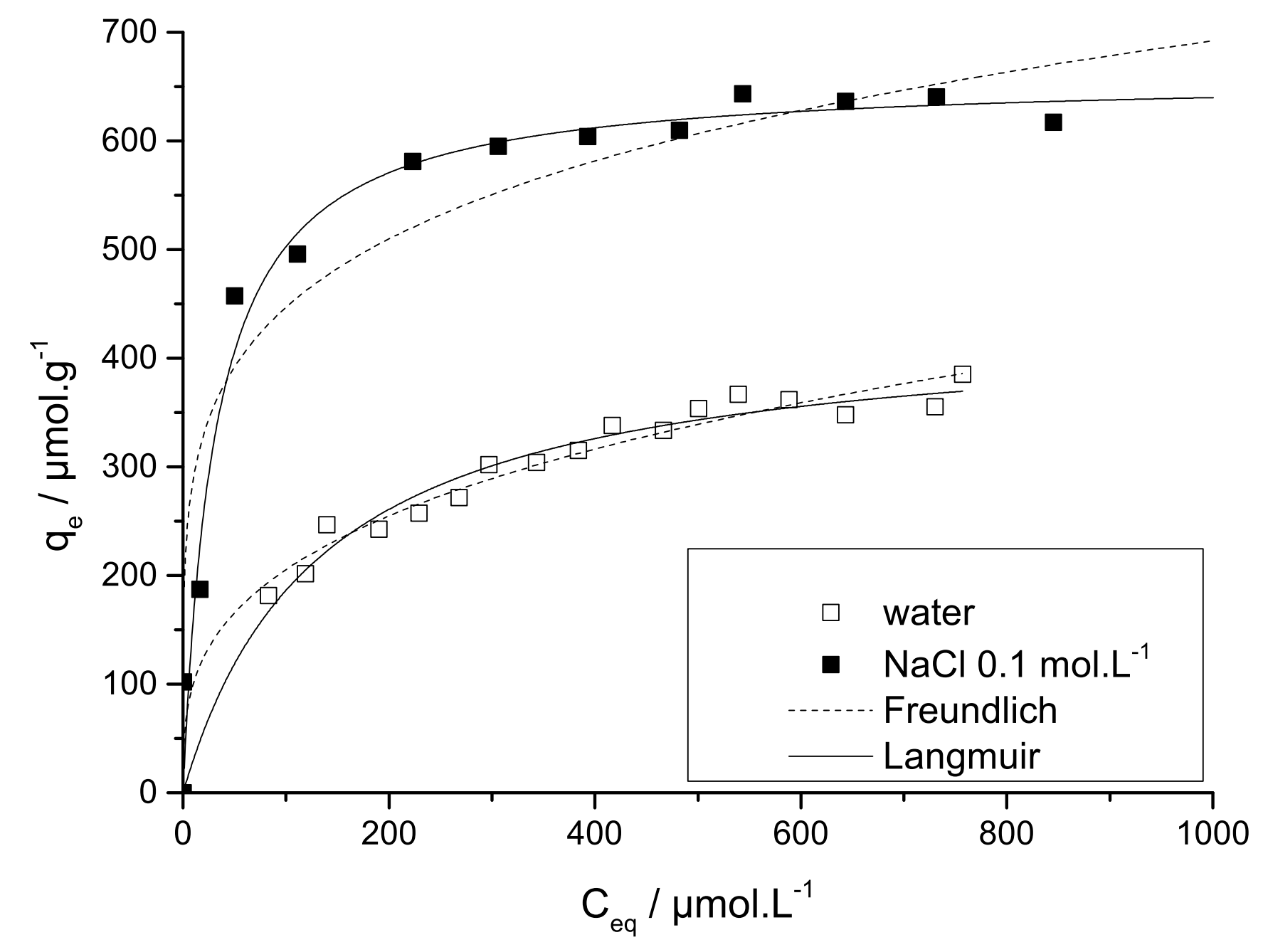

Figure $7 b$ 


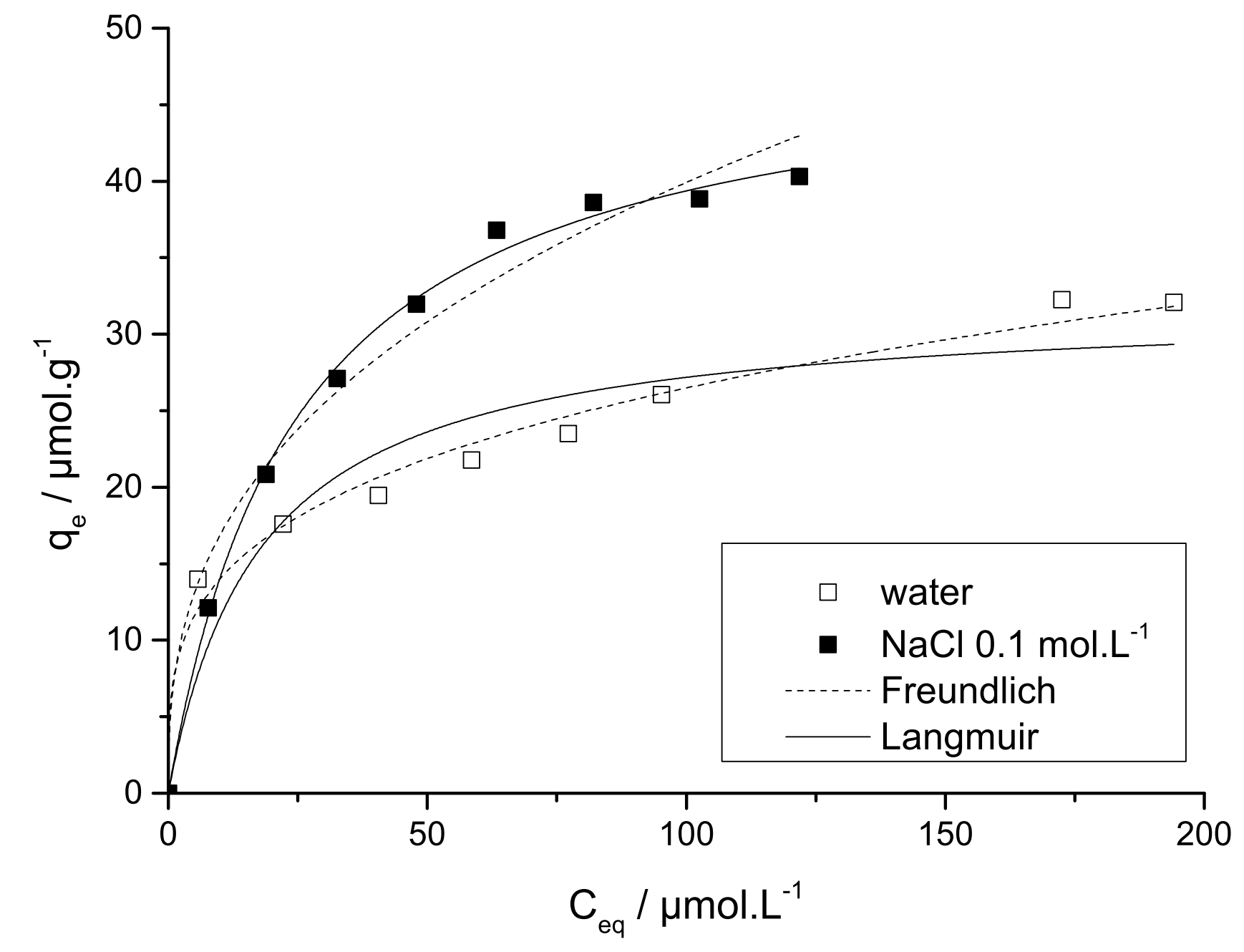

Figure 8 
Figure 9

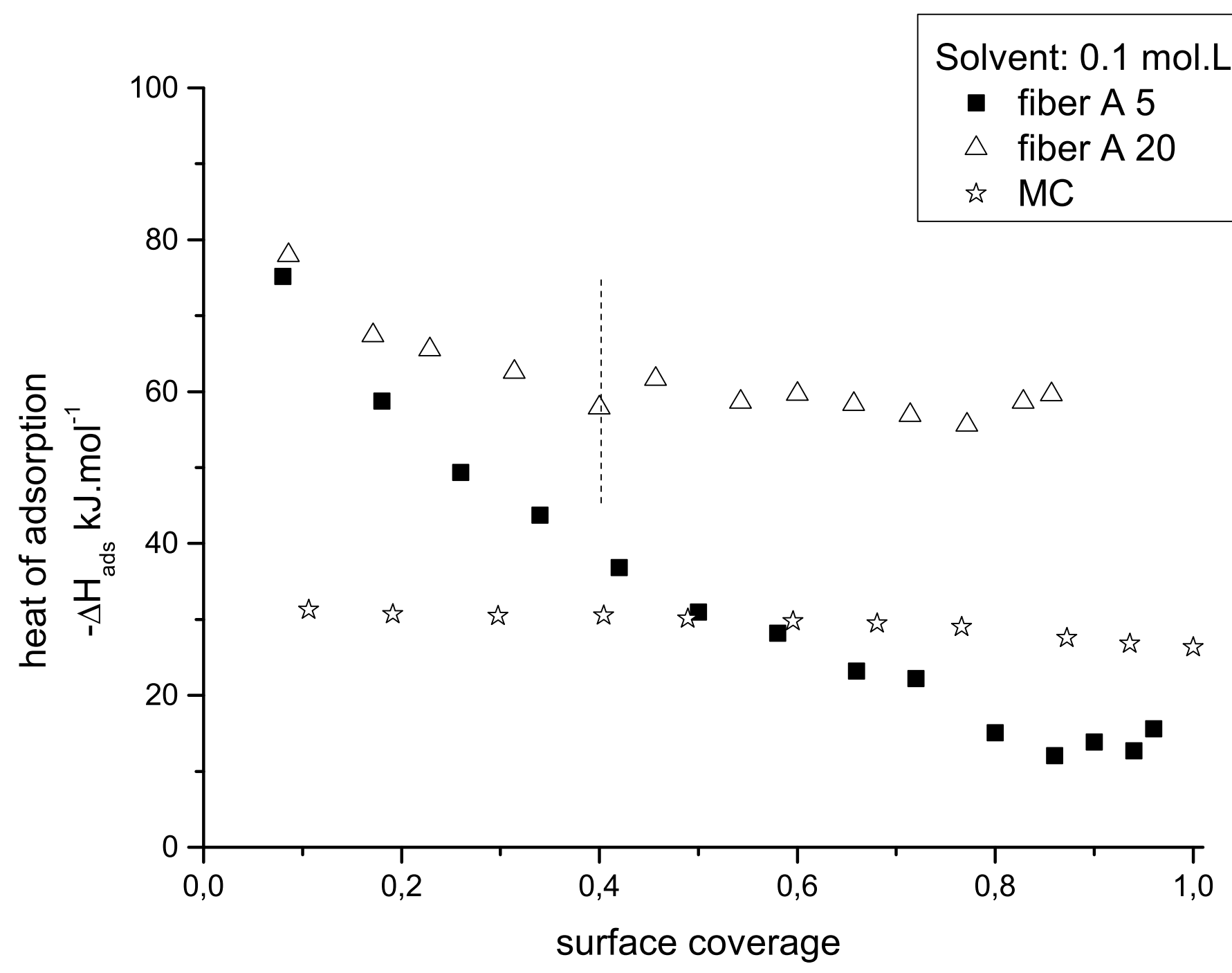




\section{Tables}

\begin{tabular}{cc}
\hline Properties & Styrene sulfonate \\
\hline Formula & $\mathrm{H}_{2} \mathrm{C}=\mathrm{CHC}_{6} \mathrm{H}_{4} \mathrm{SO}_{3} \mathrm{Na}_{\mathrm{xH}} \mathrm{O}$ \\
Molecular size $(\mathrm{nm})^{*}$ & $1 * 0.45$ \\
Molecular weight $\left(\mathrm{g} \cdot \mathrm{mol}^{-1}\right)$ & 206.2 \\
$\mathrm{pK}_{\mathrm{a}}($ at $298 \mathrm{~K})$ & 1 \\
$\lambda_{\max }$ in aqueous solution $(\mathrm{nm})$ & 255 \\
\hline$*$ determined with Cerius2
\end{tabular}

*determined with Cerius2

Table 1. The main properties of the adsorbate 


\begin{tabular}{cccccc}
\hline samples & & $\begin{array}{c}\mathrm{S}_{\mathrm{BET}} \\
\left(\mathrm{m}^{2} / \mathrm{g}\right)\end{array}$ & $\begin{array}{c}\mathrm{V}_{\text {micropores }} \\
\left(\mathrm{cm}^{3} / \mathrm{g}\right)\end{array}$ & $\begin{array}{c}\mathrm{V}_{\text {mesopores }} \\
\left(\mathrm{cm}^{3} / \mathrm{g}\right)\end{array}$ & $\mathrm{dp}$ \\
\hline A5 & fiber & 842 & 0.32 & - & $<1 \mathrm{~nm}$ \\
A20 & fiber & 1538 & 0.75 & - & Bimodal: 0.75 \\
& & & & & and $1-2$ \\
MC & mesoporous & 96 & - & 0.86 & 33
\end{tabular}

$\mathrm{S}_{\mathrm{BET}}$ : specific surface area computed using BET equation

$\mathrm{V}_{\text {TOTAL }}$ : total pore volume is estimated at a relative pressure $\mathrm{P} / \mathrm{P}^{\circ}=0.99$

$d_{p}$ pore diameter

Table 2. Textural properties of the carbons 
a) water

\begin{tabular}{|c|c|c|c|c|c|c|c|}
\hline samples & $\begin{array}{c}\mathrm{C}_{\mathrm{i}} \\
\mu \mathrm{mol} . \mathrm{L}^{-1}\end{array}$ & $\begin{array}{c}\mathrm{q}_{\mathrm{e}, \exp } \\
\mu \mathrm{mol.g}{ }^{-1}\end{array}$ & $\begin{array}{c}\mathrm{q}_{\mathrm{e}, \mathrm{calc}} \\
\mu \mathrm{mol.g} \mathrm{g}^{-1}\end{array}$ & $\begin{array}{c}\mathrm{k}_{2} * 10^{3} \\
\text { g. } \mu \mathrm{mol}^{-1} \cdot \mathrm{min}^{-1}\end{array}$ & $\mathrm{R}^{2}$ & $\begin{array}{c}\mathrm{k}_{\mathrm{a}} \\
\min ^{-1}\end{array}$ & $\begin{array}{c}\mathrm{k}_{\mathrm{d}} \\
\min ^{-1}\end{array}$ \\
\hline A5 & 100 & 130.6 & 131.6 & 0.067 & $>0.99$ & 39 & 0.005 \\
\hline A20 & 100 & 85.6 & 87.0 & 17.2 & $>0.99$ & 3607 & 0.6 \\
\hline MC & 100 & 16.1 & 16.4 & 0.23 & $>0.99$ & 82 & 0.001 \\
\hline
\end{tabular}

b) $\mathrm{NaCl}(0.1 \mathrm{M})$

\begin{tabular}{|c|c|c|c|c|c|c|c|}
\hline samples & $\begin{array}{c}\mathrm{C}_{\mathrm{i}} \\
\mu \mathrm{mol} . \mathrm{L}^{-1}\end{array}$ & $\begin{array}{c}\mathrm{q}_{\mathrm{e}, \exp } \\
\mu \mathrm{mol.g} \mathrm{g}^{-1}\end{array}$ & $\begin{array}{c}\mathrm{q}_{\mathrm{e}, \mathrm{calc}} \\
\mu \mathrm{mol} \cdot \mathrm{g}^{-1}\end{array}$ & $\begin{array}{c}\mathrm{k}_{2} * 10^{3} \\
\text { g. } \mu \mathrm{mol}^{-1} \cdot \mathrm{min}^{-1}\end{array}$ & $\mathrm{R}^{2}$ & $\begin{array}{c}\mathrm{k}_{\mathrm{a}} \\
\min ^{-1}\end{array}$ & $\begin{array}{c}\mathrm{k}_{\mathrm{d}} \\
\min ^{-1}\end{array}$ \\
\hline A5 & 100 & 52.9 & 52.9 & 12.5 & $>0.99$ & 1832 & 0.06 \\
\hline A20 & 100 & 108.9 & 108.7 & 211.6 & $>0.99$ & 82696 & 2.2 \\
\hline $\mathrm{MC}$ & 100 & 20.3 & 20.1 & 2.5 & $>0.99$ & 997 & 0.03 \\
\hline
\end{tabular}

Table 3. Pseudo-second-order kinetic parameters $\left(\mathrm{k}_{2}\right)$, adsorption $\left(\mathrm{k}_{\mathrm{a}}\right)$ and desorption $\left(\mathrm{k}_{\mathrm{d}}\right)$ constants for the adsorption of styrene sulfonate on carbons a) in water and b) in a saline solution $\left(0.1 \mathrm{~mol} . \mathrm{L}^{-1} \mathrm{NaCl}\right)$

a) Langmuir model

\begin{tabular}{|c|c|c|}
\hline Solid & water & $0.1 \mathrm{~mol} . \mathrm{L}^{-1} \mathrm{NaCl}$ \\
\hline
\end{tabular}




\begin{tabular}{|c|c|c|c|c|c|c|c|c|}
\hline phases & & & & & & & & \\
\hline & $\begin{array}{c}\mathrm{q}_{\mathrm{m}} \\
\mu \mathrm{mol} . \mathrm{g}^{-1}\end{array}$ & $\begin{array}{c}\mathrm{K}_{\mathrm{L}} \\
* 10^{-3}\end{array}$ & $\mathrm{R}^{2}$ & $\begin{array}{l}\Delta_{\text {ads }} \mathrm{G}_{\mathrm{m}}^{\circ} \\
\mathrm{kJ} \cdot \mathrm{mol}^{-1}\end{array}$ & $\begin{array}{c}\mathrm{q}_{\mathrm{m}} \\
\mu \mathrm{mol} \cdot \mathrm{g}^{-1}\end{array}$ & $\begin{array}{c}\mathrm{K}_{\mathrm{L}} \\
* 10^{-3}\end{array}$ & $\mathrm{R}^{2}$ & $\begin{array}{l}\Delta_{\mathrm{ads}} \mathrm{G}_{\mathrm{m}}^{\circ} \\
\mathrm{kJ} \cdot \mathrm{mol}^{-1}\end{array}$ \\
\hline A5 & 434.7 & 7.5 & 0.95 & -22 & 659.9 & 32.0 & 0.96 & -26 \\
\hline A20 & 618.6 & 6.6 & 0.91 & -22 & 617.4 & 37.0 & 0.94 & -26 \\
\hline $\mathrm{MC}$ & 32.0 & 56.1 & 0.69 & -27 & 49.2 & 40.2 & 0.99 & -26 \\
\hline
\end{tabular}

b) Double Langmuir model for the carbon fiber A20

\begin{tabular}{|c|c|c|c|c|c|c|c|}
\hline & $\mathrm{q}_{\mathrm{m}, 1}$ & $\mathrm{~K}_{\mathrm{L}, 1}$ & $\mathrm{q}_{\mathrm{m}, 2}$ & $\mathrm{~K}_{\mathrm{L}, 2}$ & $\mathrm{R}^{2}$ & $\Delta_{\text {ads }} \mathrm{G}_{\mathrm{m}, 1}^{\circ}$ & $\Delta_{\text {ads }} \mathrm{G}_{\mathrm{m}, 2}^{\circ}$ \\
& $\mu \mathrm{mol.g}$ & $* 10^{-3}$ & $\mu \mathrm{mol.g}$ & $* 10^{-3}$ & & ${\mathrm{~kJ} . \mathrm{mol}^{-1}}^{\mathrm{kJ} . \mathrm{mol}^{-1}}$ \\
\hline water & 196.9 & 387.6 & 668 & 1.2 & 0.99 & -32 & -18 \\
\hline $0.1 \mathrm{~mol} . \mathrm{L}^{-1} \mathrm{NaCl}$ & 254.7 & 551.0 & 440.8 & 7.3 & 0.99 & -33 & -22 \\
\hline
\end{tabular}

Table 4. Isotherms constants for styrene sulfonate adsorption on carbons in water and in a saline solution $\left(0.1\right.$ mol. $\left.\mathrm{L}^{-1} \mathrm{NaCl}\right)$ obtained with a) the Langmuir model and b) the double Langmuir model (only for the carbon fiber A20) 